\title{
In situ growth and bioerosion rates of Lophelia pertusa in a Norwegian fjord and open shelf cold-water coral habitat
}

\author{
Janina V Büscher ${ }^{\text {Corresp., } 1}$, Max Wisshak ${ }^{2}$, Armin U Form ${ }^{1}{ }^{1}$, Jürgen Titschack ${ }^{2,3}{ }^{2}$, Kerstin Nachtigall ${ }^{1}$, Ulf Riebesell ${ }^{1}$ \\ ${ }^{1}$ Biological Oceanography, GEOMAR Helmholtz Centre for Ocean Research Kiel, Kiel, Germany \\ 2 Marine Research Department, Senckenberg am Meer, Wilhelmshaven, Germany \\ 3 Marine Sedimentology, MARUM - Center of Marine Environmental Sciences, Bremen, Germany \\ Corresponding Author: Janina V Büscher \\ Email address: jbuescher@geomar.de
}

Coral reef resilience depends on the balance between carbonate precipitation, leading to reef growth, and carbonate degradation, e.g. through bioerosion. Changes in

environmental conditions are likely to affect the two processes differently, thereby shifting the balance between reef growth and degradation. In cold-water corals estimates of accretion-erosion processes in their natural habitat are scarce and solely live coral growth rates were studied with regard to future environmental changes in the laboratory so far, limiting our ability to assess the potential of cold-water coral reef ecosystems to cope with environmental changes. In the present study, growth rates of the two predominant colour morphotypes of live Lophelia pertusa as well as bioerosion rates of dead coral framework were assessed in different environmental settings in Norwegian cold-water coral reefs in a one-year in situ experiment. Net growth (in weight gain and linear extension) of live $L$. pertusa was in the lower range of previous estimates and did not significantly differ between inshore (fjord) and offshore (open shelf) habitats. However, slightly higher net growth rates were obtained inshore. Bioerosion rates were significantly higher on-reef in the fjord compared to off-reef deployments in- and offshore. Besides, on-reef coral fragments yielded a broader range of individual growth and bioerosion rates, indicating higher turnover in live reef structures than off-reef with regard to accretion-bioerosion processes. Moreover, if the higher variation in growth rates represents a greater variance in (genetic) adaptations to natural environmental variability in the fjord, inshore reefs could possibly benefit under future ocean change compared to offshore reefs. Although not significantly different due to high variances between replicates, growth rates of orange branches were consistently higher at all sites, while mortality was statistically significantly lower, potentially indicating higher stress-resistance than the less pigmented white phenotype. Comparing the here measured rates of net accretion of live corals (regardless of colour morphotype) with net erosion of dead coral framework gives a first estimate of 
the dimensions of both processes in natural cold-water coral habitats, indicating that calcium carbonate loss through bioerosion amounts to one fifth to one sixth of the production rates by coral calcification (disregarding accretion processes of other organisms and proportion of live and dead coral framework in a reef). With regard to likely accelerating bioerosion and diminishing growth rates of corals under ocean acidification, the balance of reef accretion and degradation may be shifted towards higher biogenic dissolution in the future. 
1 In Situ Growth and Bioerosion Rates of Lophelia pertusa in a Norwegian Fjord and Open 2 Shelf Cold-water Coral Habitat

3

4 Janina Vanessa Büscher ${ }^{1}$, Max Wisshak ${ }^{2}$, Armin Uwe Form ${ }^{1}$, Jürgen Titschack ${ }^{3,2}$, Kerstin

5 Nachtigall $^{1}$, Ulf Riebesell ${ }^{1}$

6

$7{ }^{1}$ Biological Oceanography, GEOMAR - Helmholtz Centre for Ocean Research Kiel, Kiel, 8 Germany

92 Marine Research Department, Senckenberg am Meer, Wilhelmshaven, Germany

$10{ }^{3}$ Marine Sedimentology, MARUM - Center of Marine Environmental Sciences, Bremen, 11 Germany

13 Corresponding author:

14 Janina Vanessa Büscher

15 Düsternbrooker Weg 20, Kiel, Schleswig-Holstein, 24105, Germany

16 Email address: jbuescher@geomar.de 


\section{Abstract}

18

Coral reef resilience depends on the balance between carbonate precipitation, leading to reef growth, and carbonate degradation, e.g. through bioerosion. Changes in environmental conditions are likely to affect the two processes differently, thereby shifting the balance between reef growth and degradation. In cold-water corals estimates of accretion-erosion processes in their natural habitat are scarce and solely live coral growth rates were studied with regard to future environmental changes in the laboratory so far, limiting our ability to assess the potential of cold-water coral reef ecosystems to cope with environmental changes. In the present study, growth rates of the two predominant colour morphotypes of live Lophelia pertusa as well as bioerosion rates of dead coral framework were assessed in different environmental settings in Norwegian cold-water coral reefs in a one-year in situ experiment. Net growth (in weight gain and linear extension) of live L. pertusa was in the lower range of previous estimates and did not significantly differ between inshore (fjord) and offshore (open shelf) habitats. However, slightly higher net growth rates were obtained inshore. Bioerosion rates were significantly higher on-reef in the fjord compared to off-reef deployments in- and offshore. Besides, on-reef coral fragments yielded a broader range of individual growth and bioerosion rates, indicating higher turnover in live reef structures than off-reef with regard to accretion-bioerosion processes. Moreover, if the higher variation in growth rates represents a greater variance in (genetic) adaptations to natural environmental variability in the fjord, inshore reefs could possibly benefit under future ocean change compared to offshore reefs. Although not significantly different due to high variances between replicates, growth rates of orange branches were consistently higher at all sites, while mortality was statistically significantly lower, potentially indicating higher stress-resistance than the less pigmented white phenotype.

Comparing the here measured rates of net accretion of live corals (regardless of colour morphotype) with net erosion of dead coral framework gives a first estimate of the dimensions of both processes in natural cold-water coral habitats, indicating that calcium carbonate loss through bioerosion amounts to one fifth to one sixth of the production rates by coral calcification (disregarding accretion processes of other organisms and proportion of live and dead coral framework in a reef). With regard to likely accelerating bioerosion and diminishing growth rates 
47 of corals under ocean acidification, the balance of reef accretion and degradation may be shifted 48 towards higher biogenic dissolution in the future. 
49

50

51

52

53

54

55

56

57

58

59

60

61

62

63

64

\section{Introduction}

Cold-water corals are important carbonate factories in the upper bathyal realm, which can build large reefs on continental shelves and slopes. Mean Holocene carbonate accumulation accounts to $103 \mathrm{~g} \mathrm{~cm}^{-2} \mathrm{kyr}^{-1}$ in Norwegian cold-water coral reefs in the North Atlantic, therewith representing significant carbonate sinks on a local and potentially even global scale (Lindberg \& Mienert, 2005; Titschack et al., 2015). Moreover, they are among the most prominent ecosystem engineers on Earth, hosting more than 2,700 species associated to cold-water coral reefs around the world, using them as nursery grounds or feeding places (Freiwald et al., 2004; Roberts \& Cairns, 2014). In contrast to their tropical counterparts, cold-water coral reefs are usually built by only one or two dominant coral species. The most abundant framework-forming cold-water coral is the caryophyllid scleractinian Lophelia pertusa (Linnaeus, 1758). L. pertusa is widely distributed and builds extended reefs in almost all oceans except for the polar regions (i.e. Cairns, 1994; Rogers, 1999; Freiwald et al., 2004). Reefs built by L. pertusa have most frequently been found in the eastern Atlantic Ocean with a dense band of reefs extending from northern Norway in the Barents Sea to the coasts of West Africa (Freiwald et al., 2004). While this is partly a consequence of higher emphasis on research efforts in these areas, the North Atlantic continental shelves and slopes appear to represent particularly suitable grounds for the development of such reefs, but Lophelia occurrences have also been documented from the Gulf of Mexico in the western Atlantic (e.g. Schroeder, 2002; Ross \& Nizinski, 2007; Brooke \& Young, 2009; Hübscher et al., 2010; Larcom et al., 2014) and the US mid-Atlantic coast (Mienis et al., 2014; Brooke et al., 2017). The reported depths of $L$. pertusa occurrences encompass a broad bathymetric range from $39 \mathrm{~m}$ to over 3,300 $\mathrm{m}$ in the North Atlantic, but L. pertusa is most commonly found between 200 and $1000 \mathrm{~m}$ (Roberts et al., 2009). L. pertusa inhabits temperatures between 4 to $13.9^{\circ} \mathrm{C}$ and salinities from 32 to 38.8 (Freiwald et al., 2004; 2009).

Cold-water coral reefs are often characterised by colonies of different colour morphotypes (in the following short: colourmorphs). In the Norwegian L. pertusa reefs the typically white coral framework is accompanied by an orange phenotype of this species. Elde and colleagues (2012) found different pigment concentrations of astaxanthin, one of the main carotenoids in Lophelia, between the colourmorphs with more than twice the content in the soft tissue and skeleton of 
orange $L$. pertusa compared to the white phenotype. To date, it is unclear whether these variations in astaxanthin content are genetically or environmentally controlled in cold-water corals. Colour variation in organisms often results from different food sources (Elde et al., 2012). In the case of Lophelia it is rather unlikely that colour variation among colonies is related solely to food sources, since orange and white specimens grow side by side and have access to the same food. Instead, it may be related to differences in the composition of bacterial communities associated to the corals as reported for $L$. pertusa, which may be linked to a nutritional advantage of the corals (Neulinger et al., 2008). Pigmentation might also be an inherited characteristic transferred from individual to individual (Elde et al., 2012), as the orange pigment was also found to be vertically transmitted to the eggs of orange specimens (Larsson et al., 2014). Moreover, a role in the function as antioxidant or antibacterial agent was suggested as potential physiological advantage of these pigments to protect the corals against pathogens and to remove particles and sediment (Shnit-Orland \& Kushmaro, 2008; Elde et al., 2012). In a recent study by Provan et al. (2016) the authors observed that the protein content of the mucus of L. pertusa varied between the two colour variants, which was suggested to be linked to the differences in mucus-associated bacterial symbionts.

Like many other deep-sea organisms, L. pertusa grows slowly, but has a long colony lifespan (Rogers, 1999). Many experimental laboratory studies report on growth rates of white L. pertusa under various conditions (e.g. Maier et al., 2009, 2012; Form \& Riebesell, 2012; Lunden et al., 2014; Hennige et al., 2014a, 2015; Büscher et al., 2017). Comparisons with growth rates in the natural habitat are scarce, as cold-water corals are difficult to access and in situ studies challenging to apply. Reported estimates of growth rates have a broad range from 2.4 to $35 \mathrm{~mm}$ per year, depending on regional differences and application of different methods, including potential sampling errors (for instance, in the complex skeletal sampling for isotope analyses) or lack of resolution (e.g. Duncan, 1877, Wilson, 1979; Mikkelsen et al., 1982; Freiwald et al., 1997; Mortensen \& Rapp, 1998; Bell \& Smith, 1999; Roberts, 2002; Orejas et al., 2008; 2011; Brooke \& Young, 2009; Lartaud et al., 2013; Larcom et al., 2014).

In situ growth estimates of $L$. pertusa typically refer to linear and radial extension rates (reviewed in Rogers, 1999; Freiwald et al., 2004; Roberts et al., 2009). The majority of in situ growth rate estimates originate from non-invasive, indirect approaches through video and still inspection of corals grown on artificial substrates such as submarine cables and energy 
110 installations (Duncan, 1877; Wilson, 1979; Larcom et al., 2014), oil and gas platforms (Bell \&

111 Smith, 1999; Roberts, 2002; Gass \& Roberts, 2006), and shipwrecks (Roberts et al., 2003;

112 Larcom et al., 2014) that allow for estimates of minimum growth rates when considering the

113 maximum age of coral colonies. Inspection of video surveys and still images revealed the highest

114 reported growth estimates of $34-35 \mathrm{~mm} \mathrm{yr}^{-1}$ (Gass \& Roberts, 2006; Larcom et al., 2014),

115 though these high growth rates of L. pertusa colonies from artificial substrates may be a result of

116 very favourable conditions with regard to currents and food availability (Mortensen, 2001;

117 Larcom et al., 2014).

118 Direct in situ measurements of linear extensions of L. pertusa were first performed by Brooke \&

119 Young (2009) by means of a one-year mark and recapture approach in the northern Gulf of

120 Mexico. The coral fragments from their experiment yielded far lower linear extension rates of

$1212.44-3.77 \mathrm{~mm} \mathrm{yr}^{-1}$ on average compared to extensions from indirect analyses. Another mark

122 and recapture study with L. pertusa from the Mediterranean Sea reported average linear

123 extension rates of $7.5 \mathrm{~mm} \mathrm{yr}^{-1}$ (Lartaud et al., 2013). No direct measurements of natural growth

124 rates were previously reported from Norwegian cold-water coral reefs, although these reefs

125 comprise the most densely populated cold-water reefs known (Freiwald et al., 2004). Laboratory

126 investigations on calcification rates revealed more than an order of magnitude lower growth rates

127 of L. pertusa from the Northeast Atlantic (0.006 - $0.009 \% \mathrm{~d}^{-1}$; Form \& Riebesell, 2012; Büscher

128 et al., 2017) compared to the Mediterranean (0.02 - $0.03 \% \mathrm{~d}^{-1}$; Orejas et al., 2011; Maier et al.,

$1292009 ; 2012)$.

130 Reef development is, however, not solely dependent on active growth of live corals. Cold-water

131 coral reefs are characterised by a large proportion of dead coral framework that accounts for

132 more than $70 \%$ of $L$. pertusa colonies (Vad et al., 2017). As for their warm-water relatives, also

133 cold-water coral reef development comprises a balance of reef accretion and degradation. The

134 proportion of living corals in an established colony was presumed to decrease compared to an

135 increasingly higher amount of dead coral framework as a result of natural reef development (Vad

136 et al., 2017). Therefore, it is important to consider the counter-acting processes of dissolution and

137 particularly bioerosion of the dead coral framework when assessing reef growth and

138 development.

139 Bioerosion is defined as "the process by which animals, plants and microbes sculpt or penetrate

140 surfaces of hard substrates" (Neumann, 1966; Bromley, 1994). In fossil and recent L. pertusa

Peer] reviewing PDF | (2019:02:34849:1:1:REVIEW 1 Jul 2019) 
141 skeletons a variety of bioerosion traces such as borings, attachment scars, and grazing traces

142 produced by a wide spectrum of organotrophic bioerosion agents (e.g. excavating sponges and

143 bryozoans, microbial bioeroders including fungi and bacteria, grazing gastropods and echinoids, 144 and parasitic foraminifers) was documented (Beuck \& Freiwald, 2005; Bromley, 2005; Wisshak 145 et al., 2005; Wisshak, 2008; Beuck et al., 2008; 2010). The majority of these bioeroders 146 chemically etch and dissolve the host substrate. This process acts particularly on the bare dead 147 coral skeleton, which lacks protection by organic tissue or defence mechanisms such as the 148 secretion of mucus (Beuck et al., 2010). Qualitative assessments of bioerosion patterns in $L$. 149 pertusa have shown that for the majority of recorded bioerosion traces, i.e. their trace makers, an 150 exclusive or at least partial chemical mode of penetration is known or inferred. This also applies 151 for the two most common organotrophic agents of bioerosion in these substrates, bioeroding 152 marine fungi and excavating hadromerid sponges. For the latter group, which often take the lion 153 share of internal macrobioerosion, several experiments with representatives of the most common 154 genus, Cliona, have demonstrated a significant increase in bioerosion capacity with increasing 155 carbon dioxide concentrations (e.g. Wisshak et al., 2012; 2013; 2014).

156 The growth of cold-water corals depends largely on environmental conditions including 157 temperature, currents, food availability, and seawater chemistry (e.g. Mortensen \& Rapp, 1998; 158 Dullo et al., 2008; Flögel et al., 2014). Ongoing ocean change may affect the capability of these 159 fragile organisms of building their calcareous skeletons, as ocean acidification caused by 160 anthropogenic carbon dioxide $\left(\mathrm{CO}_{2}\right)$ emissions results in lowered seawater $\mathrm{pH}$ and decreasing 161 carbonate ion concentrations in the oceans and consequently in a diminished calcium carbonate $162\left(\mathrm{CaCO}_{3}\right)$ saturation state (e.g. Orr et al., 2005). Carbonate chemistry investigations at cold-water 163 coral reefs and modelling assessments indicate that some L. pertusa habitats face already now

164 165 166 167 168 169 170 low carbonate ion availability and projections suggest that $\sim 70 \%$ of the known cold-water corals are expected to be exposed to calcium carbonate undersaturated waters by the end of the century due to ocean acidification (Guinotte et al., 2006; Zheng \& Cao, 2015; Georgian et al., 2016). To make reliable predictions on the growth performance of cold-water corals and reef development in the future, it is therefore important to identify the natural range of growth rates and their thresholds at current ocean conditions and bring rates measured in situ in line with rates yielded from laboratory investigations. This may also help to assess if results yielded in the 
171 laboratory might represent over-targeted accretion as potential compensation response of the

172 corals for suboptimal conditions, for example.

173 With regard to reef degrading processes under proposed future ocean conditions, empirical

174 studies on warm-water coral reef ecosystems suggest that bioerosion of $\mathrm{CaCO}_{3}$ will be

175 accelerated in the future due to the promotion of chemical dissolution through lower coral

176 skeletal densities under ocean acidification (Tribollet et al. 2006; 2009, Wisshak et al., 2012,

177 2013, 2014; Reyes-Nivia et al., 2013; and see Schönberg et al. 2017 for a review). Based on such

178 experimental data, model calculations have shown an alarming situation with regard to

179 increasingly fragile carbonate balance of coral reefs and call for local and global action

180 (Kennedy et al. 2013). These include conservation efforts and climate change mitigation

181 strategies to prevent degradation of reef structures and eventually coral reef structural collapse.

182 Despite the potentially significant effects, most studies regarding climate change related threats

183 to corals do not consider bioerosion and almost all studies including degradation processes in

184 coral reefs were carried out in tropical reef ecosystems. While studies have shown that

185 bioerosion sometimes balances or even exceeds carbonate production temporarily in tropical reef

186 ecosystems even at current ocean conditions (e.g. Perry et al., 2008), to date there is no

187 corresponding experimental data available for cold-water coral reefs. Studies of bioeroders from

188 an intermediate, cold-temperate environment suggest that the observed patterns of accelerated

189 bioerosion under future conditions may apply across species and latitudes (Wisshak et al. 2014).

190 Hence, to gain a better understanding of baseline in situ bioerosion rates of cold-water coral reef

191 substrates and to allow predictions with regard to the impacts of ocean change on reef

192 degradation, it is crucial to include bioerosion analyses in studies assessing growth in cold-water

193 coral habitats.

194 Thus, the aim of this study was to simultaneously assess in situ growth and bioerosion rates of

195 Lophelia pertusa in a one year mark and recapture experiment. We thereby compare two

196 different methodological approaches, the change in weight over time (buoyant weight before and

197 after deployment) and linear extension rates (determined via staining). In addition, we compare

198 two different cold-water coral reef locations (off-shore vs. coastal reef) in mid-Norway, allowing

199 for a better representation of the natural variability of environmentally differing reef settings.

200 Moreover, live corals of white and orange L. pertusa were compared at each location in order to

201 determine physiological differences between different colourmorphs in a reef with regard to their 
202 growth performance. Last but not least, normalisation of physiological rates will be expanded by 203 determining volume and area of each coral fragment after recovery in addition to dry weight and 204 biomass. This provides us with a variety of normalisation parameters and conversion factors 205 between them, which can be used in future cold-water coral growth studies for more easily 206 comparability. 
207

208

209

210

211

212

213

214

215

216

217

218

219

220

221

222

223

224

225

226

227

228

229

230

231

232

233

234

\section{Material \& Methods}

\subsection{Studied reef sites}

For a one year in situ growth and bioerosion rate assessment, two Norwegian Lophelia reef sites with different environmental characteristics were chosen for collection and re-deployment of live corals and dead erect coral framework. The approximately $13 \mathrm{~km}$ long and 700 metres wide Sula Reef Complex on the Sula Ridge off the coast of Sør-Trøndelag is the second largest known Lophelia reef on the Norwegian Shelf (Freiwald et al., 2002; Hovland et al., 2005). This offshore location comprises a relatively constant habitat in terms of environmental parameters such as temperature, salinity, $\mathrm{pH}$, and currents, while the selected inshore location, a reef near the island Nord-Leksa in the outer Trondheimsfjord (henceforth referred to as Leksa Reef), is exposed to a highly variable environment due to strong tidal and compensatory currents (Form et al., 2015 Cruise Report POS473). At this location the in situ experiments were placed both in the living area of the reef and in the zone of dead coral debris a few tens of metres downslope.

\subsection{Collection of Lophelia pertusa and maintenance on board}

Sampling of coral specimens of the species Lophelia pertusa was conducted with kind permission of the Norwegian Directorate of Fisheries (Fiskeridirektoratet) under permit number $12 / 17918$. Corals from the Leksa Reef were collected on $29^{\text {th }}$ and $30^{\text {th }}$ June 2013 at $63^{\circ} 36.46^{\prime} \mathrm{N}$ and $9^{\circ} 22.76^{\prime} \mathrm{E}$ and $157 \mathrm{~m}$ water depth (white specimens) and $63^{\circ} 36.43^{\prime} \mathrm{N}$ and $9^{\circ} 22.45^{\prime} \mathrm{E}$ and 152 $\mathrm{m}$ (orange specimens) during research cruise POS455 with RV POSEIDON (GEOMAR, 2015). At the Sula Reef, corals of both colourmorphs were collected on $4^{\text {th }}$ July 2013 at $64^{\circ} 06.62^{\prime} \mathrm{N}$, $8^{\circ} 07.1^{\prime} \mathrm{E}$ in $303 \mathrm{~m}$ water depth. At both sites, dead erect coral framework, bearing established bioeroder communities (chiefly bioeroding fungi, bacteria, bryozoans, and sponges), was sampled from the reef basis. All samples were collected by means of the manned submersible JAGO with its sensitive claw for non-destructive sampling (GEOMAR, 2017). On board, corals and dead coral framework were placed in large holding tanks $(120 \times 110 \times 80 \mathrm{~cm})$ filled with 500 $\mathrm{L}$ natural seawater obtained from $\sim 70 \mathrm{~m}$ depth. Four of those holding tanks were connected in 
235

236

237

238

239

240

241

242

243

244

245

246

247

248

249

250

251

252

253

254

255

256

257

258

259

260

261

262

263

order to create a recirculating system. An interconnected cooling unit (Titan 4000, Aqua Medic) kept the water temperature in the tanks at ambient seabed temperature of $7.5-8.5^{\circ} \mathrm{C}$.

\subsection{Preparation of the corals and dead erect coral framework for re- deployment}

Live coral colonies as well as dead erect coral framework were fragmented into fist-sized pieces soon after collection. Afterwards, live corals were stained with Alizarin Red S. For this purpose, live coral branches were placed in separate staining tanks $(2 \times 30 \mathrm{~L}$ plastic containers $)$ mounted within the holding tanks for temperature equilibration. The dye - pre-dissolved in ethanol - was slowly added until a concentration of $10-15 \mathrm{mg} \mathrm{L}^{-1}$ was reached according to the protocol applied in Brooke and Young (2009) for L. pertusa. Live specimens were incubated in the staining tanks for 2-3 days, as cold-water corals incorporate the dye more slowly than faster growing warm-water corals (Brooke \& Young, 2009; Form \& Riebesell, 2012). The dead framework was examined for calcifying epibionts, which were carefully removed with tweezers and a scalpel in order to eliminate weight gain due to their ongoing calcification during the experiment. All living and dead coral fragments were weighed under water following the buoyant weighing technique described by Davies (1989), employing a Sartorius BP 310 P (d= $0.001 \mathrm{~g}$ ) with a purpose built free hanging weighing gondola to enable weighing on board the vessel and to reduce transmission of vibrations onto the balance. Weighing on board was performed at very calm sea, but was nevertheless unsteady. Therefore, the average of ten consecutive values was taken for each fragment to improve precision. Shortly before deployment of the fragmented and stained corals, one white and one orange coral fragment were attached with cable ties inside a 'coral cage' (168 x 178 x 156 mm PP Nalgene ${ }^{\circledR}$ autoclave baskets). Four such coral cages were prepared for each study site.

Bioeroded coral fragments were attached in smaller baskets $\left(123\right.$ x 154 x 105 mm, PP, Nalgene ${ }^{\circledR}$ autoclave baskets). For each location six 'bioerosion cages' filled with dead coral framework material were weighed under water using the buoyant weighing technique (Davies, 1989) and attached as a cluster for facilitating deployment and recovery. In bioeroded dead L. pertusa framework, a number of successive stages of bioerosion, characterised by certain bioerosion 
264 trace assemblages, have been identified (Beuck et al. 2010). For the purpose of our experiment,

265 we attempted to distribute skeletons of these different bioerosion stages (stages 3 to 6 sensu

266 Beuck et al. 2010) as evenly as possible to the different replicates and locations, though the

267 amount of bioeroders per fragment can still vary considerably. As in Sula only little and

268 relatively young dead coral framework could be collected, the material in the Sula cages

269 comprised a mixture of dead erect coral framework from both collection sites in Sula and Nord-

270 Leksa. Apart from this, we attempted to distribute skeletons as evenly as possible to the different

271 replicates and locations with regard to their appearance of bioerosion stages.

\subsection{Deployment and recovery of coral and bioerosion cages}

274

275

276

277

278

279

280

281

282

283

284

285

286

287

288

289

290

291

292

293

Four coral cages and six bioerosion cages were deployed simultaneously at each of the three deployment locations, two at the inshore reef south of Nord-Leksa and one at the offshore Sula Reef in July 2013. To assure constant submersion in seawater, the cages were immersed in a sampling box installed in front of JAGO filled with seawater before lifting the submersible into water. On the ground, the baskets were positioned at the desired locations one by one by with the submersible's manipulator arm. At the first Leksa station (Leksa on-reef), the cluster and the coral cages were placed into a living reef area at $180 \mathrm{~m}$ water depth (Fig. 1a). At the second Leksa location (Leksa off-reef), baskets were placed on the bare sediment off the live reef zone at $218 \mathrm{~m}$ (Fig. 1b) to determine whether coral survival and growth is also supported in areas of no coral growth in the vicinity of the living reef. At the Sula Reef Complex (Sula), coral cages and the bioerosion cluster were deployed at the southernmost third of the reef chain in a small depression almost completely engulfed by the live reef at $304 \mathrm{~m}$, about $50-100 \mathrm{~m}$ away from the nearest living Lophelia colonies. Unfortunately, in Sula no coral baskets could be deployed into the living reef structures because of limited dive possibilities due to rough weather conditions.

After one year, in July/August 2014, all locations were revisited with RV POSEIDON (POS473) and all coral cages and bioerosion clusters were recollected by means of JAGO and brought back aboard (permit number 14/1781 of Directorate of Fisheries for cruise POS473), where they were immediately transferred to large holding tanks. Except for one coral cage in the Leksa off-reef location, all coral cages and clusters could be retrieved. Soon after recovery, the coral fragments 
294

295

296

297

298

299

300

301

302

303

304

305

306

307

308

309

310

311

312

313

314

315

316

317

318

319

320

321

322

and bioerosion cages were weighed on board following the same protocol and using the same equipment as outlined above. Afterwards, all samples were dried at $60{ }^{\circ} \mathrm{C}$ on board and cushioned packed for later laboratory analyses.

\subsection{Post-cruise analyses}

After the cruise, all samples were dried at $70{ }^{\circ} \mathrm{C}$ for several days until constant weight was reached. Dry weights of empty baskets, cable ties, and corals were separately measured. Calcifying epibionts grown on the dead erect coral framework as well as on the live coral fragments (carbonate accretion) over the year of exposure were removed with a scalpel and weighed separately after drying to constant weight. Then, all samples were scanned via computed tomography (CT) for volume and surface area analysis (see detailed description of the methods in 2.5.1), before linear extension rates of the 'live' coral fragments were determined by measuring the distance from the Alizarin Red S band of each corallite to the rim of the calyx using a digital calliper. As growth of the calices is sometimes more pronounced on one side of the calyx than on the other, this measurement was done on two opposing sides, with the lowest and the highest distance between stain bands and rim of each corallite. In addition, the numbers of newly grown (completely unstained) corallites, as well as the number of died polyps (calices without tissue) of the 'live' coral fragments were counted. When being deployed in 2013 it was made sure that only intact corallites remained on the fragments, while all empty corallites were removed. Counted newly grown corallites and dead polyps were compared to the total number of corallites of each branch to assess budding rate as well as mortality as a percentage over the course of the experiment. Finally, all samples were dried again to constant weight and combusted at $500{ }^{\circ} \mathrm{C}$ for 5 hours for differentiation of organic versus inorganic content.

The densities of the coral's skeletons were empirically assessed from small fragments cut off each branch of white, orange and dead coral fragments of each replicate (in case of the dead coral framework only three of the six replicates were subsampled for this purpose). All fragments were dried to constant weight at $68^{\circ} \mathrm{C}$ before tissue residuals were removed with chlorine bleach according to the method described by Davies (1989). Afterwards, the buoyant weight of the fragments without tissue residuals was measured. In order to get rid of all 
323 accumulated air bubbles within the skeletal structures, fragments were treated in a vacuum

324 drying cabinet in beakers filled with seawater, so that the weights were not falsified by additional

325 buoyancy. After being washed in distilled water, the fragments were dried and weighed again

326 until constant weight was reached and the skeletal densities were calculated from the following

327 equation following the method by Davies (1989):

$\delta_{\text {Skeleton }}=\frac{\delta_{s w}}{\left(1-\frac{B W}{D W}\right)}$

329

with $\delta s w=$ density of the seawater, $B W=$ buoyant weight of the coral fragments without tissue, and $D W=$ the dry weight of the fragments without tissue.

\subsubsection{CT scanning}

CT scans of all dried samples ('live' coral fragments and dead framework) for volume and surface area analyses were carried out with a Toshiba Aquilion 64 computer tomograph at the hospital Klinikum Bremen-Mitte with a voltage of the x-ray source of $120 \mathrm{kV}$ and a current of $600 \mathrm{~mA}$. The resulting CT image stacks have a resolution of $0.35 \mathrm{~mm}$ in $\mathrm{x}$ - and $\mathrm{y}$-direction and $0.5 \mathrm{~mm}$ resolution in $\mathrm{z}$-direction $(0.3 \mathrm{~mm}$ reconstruction unit). Images were reconstructed using Toshiba's patented helical cone beam reconstruction technique (TCOT) and are provided in DICOM-format. The data were processed with the ZIB edition of the Amira software (version 2013.47) (Stalling et al., 2005). With Amira, the corals were segmented with the Multi-

Thresholding module (threshold value: 0 ). The segmentation result was evaluated and the coral cage was removed from the computation of each sample with the Segmentation Editor. Afterwards, the Generate-Surface module was used to compute a surface model of the coral specimens. Finally, the volume and the area of the specimens were determined using the Surface Area Volume module.

\subsection{Calculations and statistical analyses}

Growth and bioerosion rates were calculated according to descriptions in Davies (1989) based on buoyant-weight gain or loss of the coral skeleton over time. The gained rates were normalised to 


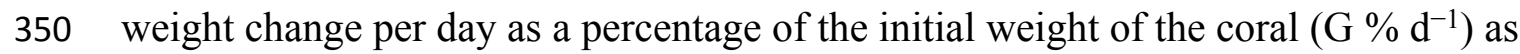

351 parameterisation predominantly used in experimental studies with live corals applying the

352 buoyant weighing technique. In addition, rates were normalised to weight change in grams per

353 square metre coral surface (gained from the CT measurements) per year $\left(\mathrm{g} \mathrm{m}^{2} \mathrm{yr}^{-1}\right)$, which

354 represents the most common unit in bioerosion studies. Data are depicted as mean \pm standard

355 deviation (SD). Statistical analyses were performed using SigmaPlot@ (version 12.0; Systat

356 Software Inc.) and MS Excel. For statistically comparing the results between the three locations

357 of white as well as orange coral colourmorphs, One-way Analysis of Variance tests (ANOVAs)

358 were carried out with $n=4$ replicates per location, except for the Leksa off-reef location at which

359 one basket and therewith one orange and one white replicate were missing. In case of statistical

360 differences, a post-hoc test for pairwise multiple comparisons following the Holm-Sidak method

361 was carried out to distinguish differences among groups/locations. Whenever data were pooled

362 to increase the sample size and statistical power, this was done upon confirmation that there were

363 no significant differences in the ANOVAs. For direct comparisons of white and orange corals or

364 only two locations, $t$-tests were performed. In order to obtain more accurate and reliable means

365 for conversion factor calculations, outlier tests were carried out in MS Excel (Excel QUARTILE

366 and OR functions). 


\section{Results}

369

\section{$370 \quad 3.1$ Coral structural analyses}

371 Coral surface area, volume, corallite number, and skeletal density of live and dead coral

372 fragments (Table 1) were gathered post-experiment after recovery of the coral and bioerosion

373 baskets. Volume and surface area were significantly different between live corals from both

374 Leksa sites and the Sula Reef in both colourmorphs ( $p \leq 0.001$; One-way ANOVAs), with

375 significantly less bulky coral fragments deployed in Sula compared to both Leksa locations.

376 While Leksa corals had $119 \pm 44$ polyps/corallites per fragment on average, the Sula corals had

377 only $35 \pm 11$ polyps per branch (Table 1). This is attributable to the different morphology of the

378 offshore corals. While fjord colony growth is more compact, offshore coral growth tends to be

379 more extended and branched, which corresponds to lower polyp numbers as well as surface area

380 and volume in Sula despite similar fragment sizes like the Leksa fragments. Both surface area

381 and volume of the coral branches correlated well with polyp count $\left(\mathrm{R}^{2}=0.7\right)$ with a slightly

382 better correlation of surface area with total polyp count than volume. Figure 2 shows exemplary

383 CT scan images of a live coral fragment (A), and dead coral framework (B) from one basket of

384 the cluster.

385 Mean skeletal density of all live corals was $2.734 \pm 0.043 \mathrm{~g} \mathrm{~cm}^{-3}$. Orange corals had a slightly

386 lower skeletal density $(<1 \%)$ by trend than white corals. Note that the skeletal density of the

387 orange coral fragments from the Sula Reef was considerably lower than the densities of all other

388 fragments and was identified as outlier by means of an outlier test (MS Excel QUARTILE and

389 OR functions). The outlier values were therefore omitted from the average skeletal density of

390 live corals. Bioeroded skeleton material had slightly higher densities than live corals averaging

$3912.758 \pm 0.031 \mathrm{~g} \mathrm{~cm}^{-3}$. Both, white vs. orange live as well as bioeroded vs. live coral skeletons

392 were not significantly different in densities ( $t$-tests). For the calculation of growth and bioerosion 393 rates the specific density means of live or bioeroded skeleton material was used. 
395

396

397

398

399

400

401

402

403

404

405

406

407

408

409

410

411

412

413

414

415

416

417

418

419

420

421

422

423

\subsection{Mortality of live Lophelia fragments}

Polyp mortality of the branches was quite variable between the replicates within and among locations, ranging from $0-86 \%$ dead polyps per branch. The highest variability was found in the Leksa on-reef location (Fig. 3). There was no statistically significant difference in mortality rates between locations (white and orange live coral branches separately tested or pooled). However, lowest mortality was found in Sula with only half as many dead polyps as a percentage of the total polyp count of a branch $(10 \pm 14 \%)$ as in the Leksa off-reef location $(21 \pm 19 \%)$ and one third of the percentage of the Leksa on-reef group (30 $\pm 27 \%)$. Comparison of polyp mortality between white and orange fragments (Fig. 4) revealed a statistically significant difference when white and orange corals were pooled over all three locations $(p=0.002$; MannWhitney Rank Sum Test). While the orange coral fragments had on average $8 \pm 9 \%$ dead polyps per replicate, the white corals had $33 \pm 23 \%$ (Table 2 ).

\subsection{Linear extension rates}

The overall mean extension rate of all stained corallites of the living coral branches (not all corallites incorporated the dye) from all sites was $2.12 \pm 0.86 \mathrm{~mm} \mathrm{yr}^{-1}(\mathrm{n}=18$; Table 3$)$. Examples of coral branches with corallites showing the Alizarin Red S band are depicted in the photographs in figure 5. There were no statistically significant differences in average linear extension rates of the replicates, neither between the three locations (One-Way ANOVA) nor between colourmorphs ( $t$-test) (Fig. 6). Nevertheless, the orange specimens tended to have $\sim 15$ $\%$ higher linear extensions than the white ones (pooled over all locations: $2.31 \pm 0.90 \mathrm{~mm} \mathrm{yr}^{-1}$; $\mathrm{n}=8$ (orange) versus $1.96 \pm 0.84 \mathrm{~mm} \mathrm{yr}^{-1} ; \mathrm{n}=10$ (white); Table 3). However, especially the orange corals showed high variances between replicates, which was pronounced most strongly in the onreef replicates of Leksa, similarly to weight gain. Moreover, Sula corals showed considerably lower growth ( $46 \%$ less average linear extension) compared to inshore sites. Within the orange coral group this is, however, based on only one replicate of the Sula location as the dye was visibly incorporated in only one of the four replicates at Sula. Thus, averaging all Leksa corals regardless of white or orange from both Leksa sites and comparing Leksa and Sula extension rates revealed a statistically significant difference with $\sim 44 \%$ higher extension rates 
$424\left(p=0.03\right.$; $t$-test; $2.34(\mathrm{n}=14)$ vs. $1.31 \mathrm{~mm} \mathrm{yr}^{-1}(\mathrm{n}=4)$; Fig. 7). Average linear extension rates

425 correlated well with weight gain in percent per day $\left(\mathrm{R}^{2}=0.83\right)$.

426 The amount of newly grown corallites that developed after staining was similar in all locations 427 and averaged $47.4 \pm 12.5 \%$. New corallites alone had significantly higher extension rates $(p=$ 4280.043 ; $t$-test) than all stained polyps of the branches (total extensions; including newly grown 429 polyps and all corallites where staining bands could be determined). Mean linear extension of 430 newly grown polyps/corallites over all locations and specimens was $2.84 \pm 1.04 \mathrm{~mm} \mathrm{yr}^{-1}$ 431 compared to $2.11 \pm 0.86 \mathrm{~mm} \mathrm{yr}^{-1}$ total extension on average (Fig. 8), and compared to $1.87 \pm$ $4320.59 \mathrm{~mm} \mathrm{yr}^{-1}$ when taking only the "old" stained corallites alone $(p=0.003$; t-test comparing 433 newly grown and stained corallites excluding newly grown). Comparing new vs. total extensions 434 (averaged over all stained and newly grown corallites) of the different groups shows that the 435 greatest effect of new growth took place in the Leksa on-reef location. On-reef, 60 - $75 \%$ higher 436 linear extension rates of new corallites of white and orange specimens were gained, while in the 437 Leksa off-reef location it was less than half as much (20 - $33 \%$ ). In Sula, growth rates of newly 438 grown corallites were not different or even lower than total stained corallites, although the 439 440 percentage of newly grown corallites per branch was similar to the percentage of newly grown polyps on the Leksa branches. As newly grown corallites make up for almost half of all stained corallites the pattern of the slight differences between location and/or colourmorph is similar to average extensions of all (old and young) corallites.

\subsection{Calcification rates of live corals}

Overall net carbonate production rate of all observed live coral fragments based on buoyant weight measurements (standard deviation of the ten consecutive measurements of each fragment of the Leksa weighing session $=0.052 \mathrm{~g}$ and Sula weighing session $=0.082 \mathrm{~g}$ ) was $0.0122 \pm$ $0.0103 \% \mathrm{~d}^{-1}$ or $61.7 \pm 48.2 \mathrm{~g} \mathrm{~m}^{-2} \mathrm{yr}^{-1}(\mathrm{n}=22$; Fig. 9; Table 3). Mean values of white and orange coral fragments averaged over all locations were $0.0107 \pm 0.0057 \% \mathrm{~d}^{-1}$ or $56.02 \pm 32.01 \mathrm{~g} \mathrm{~m}^{-2}$ $\mathrm{yr}^{-1}(\mathrm{n}=11)$ and $0.0138 \pm 0.0137 \% \mathrm{~d}^{-1}$ corresponding to $67.42 \pm 61.51 \mathrm{~g} \mathrm{~m}^{-2} \mathrm{yr}^{-1}(\mathrm{n}=11)$, corals (averaged over all locations; $t$-test), nor between the different sites (One-way ANOVAs). 
453 However, corals from Sula Reef generally showed lower calcification rates with only half as

454 much $\mathrm{CaCO}_{3}$ precipitation on average (48\%) as the Leksa off-reef corals when comparing all

455 live corals (white and orange pooled) of the single sites ( $p=0.029 ; t$-test). Although growth rates

456 in the top reef replicates in Leksa on-reef were even higher on average than at the Leksa off-reef

457 site, the top reef corals were not significantly different from the Sula corals. A similar

458 comparison of all inshore vs. offshore replicates as for the linear extension rates (compare Fig. 7)

459 revealed a similar picture with $50 \%$ higher growth rates in weight gain in $\% \mathrm{~d}^{-1}$, though not

460 statistically significant due to the high variability in the Leksa on-reef location $\left(0.015 \% \mathrm{~d}^{-1}\right.$

$461(n=14)$ vs. $\left.0.0074 \% \mathrm{~d}^{-1}(n=8)\right)$. Differences between the different locations and between the two

462 colourmorphs of L. pertusa are shown in figure 10.

3.5 Bioerosion rates and epibiont carbonate accretion rates of dead erect coral 465 framework

466 Carbonate degradation rates presumably resulted primarily from bioerosion processes, as the aragonite saturation of the seawater was supersaturated at all locations at the time of deployment

468

469

470

471

472

473

474

475

476

477

478

479

480

481

482 as well as recovery of the cages $(\Omega>1.7$; Table 4$)$ and seasonal undersaturation $(\Omega<1)$ is expected very unlikely. Thus, physicochemical dissolution of the corals' skeleton is considered negligible here and degradation rates are referred to as bioerosion rates in the following. Bioerosion rates of the dead erect framework integrated over all locations (expressed here as negative values for indicating a loss in weight as opposed to the gain in weight by coral calcification) was $-0.0020 \pm 0.0015 \% \mathrm{~d}^{-1}$, corresponding to $-12.37 \pm 9.40 \mathrm{~g} \mathrm{~m}^{-2}$ coral surface $\mathrm{yr}^{-1}$ (Fig. 9). Highest degree of bioerosion took place in the Leksa on-reef location with $-0.0036 \pm$ $0.0012 \% \mathrm{~d}^{-1}$ or $-23.20 \pm 7.87 \mathrm{~g} \mathrm{~m}^{-2} \mathrm{yr}^{-1}$, which was $74 \%$ higher than the off-reef site in Leksa with $-0.0009 \pm 0.0007 \% \mathrm{~d}^{-1}$ or $-5.88 \pm 4.42 \mathrm{~g} \mathrm{~m}^{-2} \mathrm{yr}^{-1}$ and $64 \%$ higher than the offshore location Sula with $-0.0013 \pm 0.0003 \% \mathrm{~d}^{-1}$ or $-8.03 \pm 2.24 \mathrm{~g} \mathrm{~m}^{-2} \mathrm{yr}^{-1}$. Values from the on-reef Leksa location were statistically different from both off-reef placements ( $p \leq 0.001$; One-Way ANOVA; Fig. 10; Table 5), despite highest variation between replicates in the on-reef site. The off-reef locations (in Leksa and Sula) were not significantly different from one another.

Carbonate accretion by calcifying epibionts that grew during the one year of exposure was $0.0029 \pm 0.0013 \% \mathrm{~d}^{-1}\left(18.48 \pm 8.54 \mathrm{~g} \mathrm{~m}^{-2} \mathrm{yr}^{-1}\right)$, accounting for about one-fourth $(23.7 \%)$ of the 
483 growth in percent per day of the living corals (Fig. 9; Table 5). However, this number has to be 484 taken with caution, as particularly accretion might be subject to estimation errors. Intensity of 485 carbonate accretion in the dead framework was found to covary with the observed bioerosion 486 rates, with highest accretion in the Leksa on-reef location and lower accretion rates in both off487 reef sites. Carbonate accretion differed significantly only between the Leksa on-reef location and 488 the Sula Reef ( $p=0.006$; One-Way ANOVA; Table 5; Fig. 10).

489 Similar to the growth rates of living corals, bioerosion as well as accretion rates showed the 490 highest variability of rates (highest standard deviation of the mean) at the on-reef location.

\subsection{Conversion Factors}

493

494

495

496

497

498

499

500

We used various methods for growth rate measurements as well as for the normalisation of the different variables, and are thereby able to provide conversion factors for coral growth in size and weight and for the standardisation of these data (Table 6). Since there were no statistically significant differences between colourmorphs and locations, conversion factors for growth rates based on differences in buoyant weight or linear extension rates as well as buoyant weight vs. dry weight, dry weight vs. volume and surface area, and weight, volume or surface area vs. number of polyps were averaged across all samples of live corals. Weight, size, and polyp number correlated well ( $\mathrm{R}^{2}$ ranging from $\left.0.616-0.999\right)$. 
502 Discussion

503

504 In this in situ study, net growth- as well as bioerosion rates from environmentally contrasting 505 cold-water coral ecosystems were obtained in a one year experiment in a Norwegian fjord and 506 open shelf coral reef environment in the Northeast Atlantic using complementing established 507 standard methods. In situ net calcification rates of healthy calcifying living L. pertusa of 508 different morphological structure and colour were $0.011 \% \mathrm{~d}^{-1}$ on average over three different 509 reef sites. Bioerosion rates of dead erect coral framework averaged $-0.002 \% \mathrm{~d}^{-1}\left(-12.37 \mathrm{~g} \mathrm{~m}^{-2} \mathrm{yr}^{-}\right.$ $51{ }^{1}$ ) of the same reef habitats (disregarding the relatively high accretion rates of epibionts).

511 Calculating a net production rate of accretion and bioerosion of live and dead coral fragments of

512 this experiment is not legitimate, as here two different sample sizes are compared. For this 513 reason we refrained from adding up calcification rates of living corals and erosion rates of dead 514 coral framework, since the obtained rates do not reflect the actual reef carbonate budget, which

515 would demand the determination of the proportions of live and exposed dead coral framework in 516 a given reef. However, considering that bioerosion rates amounted to one fifth to one sixth of 517 calcium carbonate loss compared with the production rates through coral calcification in this 518 direct comparison, it can be assumed that the carbonate balance of accretion and bioerosion in 519 cold-water coral reefs could be shifted towards higher biogenic dissolution in the future under 520 ocean change. Supposing that the relative proportions in this one-to-one relationship are roughly 521 correct and reef base degradation increases with acidification (compare Tribollet et al. 2006; 522 2009, Wisshak et al., 2012, 2013, 2014; Reyes-Nivia et al., 2013) this might even lead to net 523 negative carbonate budget states. Some tropical coral reefs experience already now negative net 524 balanced carbonate budgets (e.g. Perry et al., 2014). While in some areas cold-water corals are 525 found to grow in unfavourable conditions with regard to carbonate chemistry (Gómez et al., 526 2018), it is not known for these systems whether they are in net production or dissolution state.

527 With regard to projected changes in seawater conditions in the future, bioerosion is expected to 528 increase in warm-water reef systems, particularly driven by sponges (e.g. Wisshak et al., 2012; 529 2013). Considering a doubling to quadrupling of chemical bioerosion through sponges in warm530 water reefs under different end-of-the-century $p \mathrm{CO}_{2}$ scenarios (Wisshak et al., 2013), cold-water 531 coral reef resilience could become significantly impacted by bioerosion under ongoing ocean 532 acidification, if similar enhanced bioerosion effects will become apparent in cold-water coral 
533 framework. Indeed, enhanced degradation may particularly become apparent in cold-water coral

534 reefs considering that the calcium carbonate saturation in cold, deep waters is considerably lower

535 than in shallow tropical environments. Since likely higher bioerosion rates can be expected from

536 older Lophelia framework stages in the centre of the reef structures than from the material used

537 here, a quadrupling of bioerosion rates could lead to higher degradation than accretion gained

538 through calcification in cold-water coral reefs in a high $\mathrm{CO}_{2}$ world.

\section{Growth \& mortality of living corals}

\section{Growth rates}

541 Net growth rates of live corals in the experiment ranged from 0.001 to $0.049 \% \mathrm{~d}^{-1}$ in weight gain

542 (calcification) and 1.00 to $4.05 \mathrm{~mm} \mathrm{yr}^{-1}$ in average linear extension. These values are in the lower

543 range of literature values both in terms of buoyant weight measurements and length growth

544 assessments (e.g. Brooke \& Young, 2009; Maier et al., 2009; Orejas et al., 2011; Lunden et al.,

545 2014; Büscher et al., 2017). Buoyant weight measurements were usually applied in laboratory

546 experiments, since on-board weighing comprises a difficult task due to the ship's vibration and

547 movement. Moreover, weighing of slow-growing coral fragments in particular requires very

548 precise underwater weighing and a very careful handling during deployment and recovery of the

549 weighed samples to not lose any bits of the corals by breakage. With a mean value of $0.011 \% \mathrm{~d}^{-1}$

550 for white coral specimens measured in this in situ experiment, growth rates are slightly higher

551 than rates obtained in the lab with corals from different Norwegian reef sites ranging from 0.006

$552 \% \mathrm{~d}^{-1}$ for corals from Nord-Leksa (Büscher et al., 2017), over $0.007 \% \mathrm{~d}^{-1}$ for Oslofjord corals to

$5530.009 \% \mathrm{~d}^{-1}$ for Sula Reef corals (Form \& Riebesell, 2012) at ambient temperatures. Higher

554 growth rates of Norwegian corals were obtained by specimens kept at an elevated temperature of

$55512{ }^{\circ} \mathrm{C}\left(0.006-0.029 \% \mathrm{~d}^{-1}\right.$, Büscher et al., 2017), which were in a comparable range with rates

556 of L. pertusa from the Mediterranean Sea at similar temperature $\left(0.02 \pm 0.01 \% \mathrm{~d}^{-1}\right.$; Orejas et al.,

557 2011; Maier et al., 2009, 2012). Those relatively high growth rates were also reached by some

558 individual Norwegian specimens in the present in situ experiment at $7-8{ }^{\circ} \mathrm{C}$. Short-term $(14$

559 days) calcification rates of L. pertusa from the Gulf of Mexico measured in the laboratory with

560 the buoyant weighing technique were more than twice as high $\left(0.025 \pm 0.006 \% \mathrm{~d}^{-1}, \mathrm{n}=16\right)$ on

561 average (Lunden et al., 2014), while a longer-term study (6 months) with corals from this area 
562 yielded rates at ambient conditions that were comparable to Norwegian corals (Kurman et al., 563 2017). Lunden et al. (2014) observed quite a broad range of average calcification rates in their 564 experiment, ranging from 0.002 to $0.091 \% \mathrm{~d}^{-1}$. Such rather high variances between fragments 565 even at similar environmental conditions as likewise observed in this study display the very high 566 plasticity of L. pertusa with regard to its performance, which was experienced in several 567 investigations of this species (Mortensen, 2001; Brooke \& Young, 2009; Form \& Riebesell, 568 2012, Lunden et al., 2014; Hennige et al., 2015; Büscher et al., 2017; Kurman et al., 2017). 569 Kurman et al. (2017) found varying growth responses of different genotypes of L. pertusa 570 exposed to acidified conditions, with some genotypes withstanding the same conditions longer 571 than others. The authors hypothesised that some genotypes may prove to be more resilient 572 towards ocean change than others showing that L. pertusa may contain the genetic variability 573 necessary to support adaptive responses to changing conditions in the future (Kurman et al., 574 2017). Thus, the broad range in growth rates may also result from genetic variability across 575 colonies.

576 With regard to linear extensions, it is rather difficult to compare measured rates with literature 577 values obtained from different methods (video survey, isotopic fractionation, artificial substrate 578 observations, mark and recapture) and with different perspectives or intentions (i.e. determining 579 the highest possible growth rate vs. average growth rate). Growth estimates from indirect 580 analyses vary widely with extension rates from approximately 3.2 to $34.7 \mathrm{~mm} \mathrm{yr}^{-1}$ (i.e. 581 Mikkelsen et al., 1982; Freiwald et al., 1997; Mortensen \& Rapp, 1998; Bell \& Smith, 1999; 582 Roberts, 2002; Gass \& Roberts, 2006; Larcom et al., 2014). The broad range of extension rates 583 indicates site-specific differences, although it cannot be excluded that the different sampling 584 techniques might contribute to the variations in results. While non-destructive indirect methods 585 like video surveys might lead to both, underestimation of growth rates with unknown initiation 586 of colony development as well as overestimation due to determination of only the largest and 587 fastest growing colonies, direct analyses through e.g. mark and recapture approaches likely yield 588 underestimated growth rates because of the handling impacts to the corals. For example, the 589 staining of the corals with Alizarin Red S was argued to impact the coral's growth recovery, 590 leading to underestimated in situ natural growth of cold-water corals even in long-term 591 approaches (Lartaud et al., 2017). 
592 Highest linear extension rates were obtained through visual inspections via video surveys from 593 corals grown on artificial substrates with known time of installation with maximum reported 594 rates of $34.7 \mathrm{~mm} \mathrm{yr}^{-1}$ in an individual colony (Gass \& Roberts, 2006; Larcom et al., 2014). While 595 the average of the largest corals from various platforms and depths $(300-800 \mathrm{~m})$ of the same 596 study by Larcom et al. (2014) comprise already lower rates of $21 \mathrm{~mm} \mathrm{yr}^{-1}$, this reduces even 597 further to about $17 \mathrm{~mm} \mathrm{yr}^{-1}$ when considering the largest $10 \%$ of all colonies (Larcom et al., 598 2014). Although the estimated growth rates might comprise an underestimation of potential 599 maximum growth, since the calculations assume immediate settling after installation of the 600 structures, the average extension rates in the mentioned studies likely represent above-average 601 growth rates of the largest and most elongated colonies. On the other hand, corals growing on 602 artificial substrates are situated in an exposed position well above the seafloor with unimpeded 603 access to food particles and directed into the currents (Mortensen, 2001; Gass \& Roberts, 2006; 604 Larcom et al., 2014), which might support exceptionally high extension rates in individual 605 colonies. Thus, coral growth on man-made structures constitutes in a way pioneer growth, with 606 colonies being able to extend in all directions and therefore gaining very high extension rates, 607 whereas in already established reefs it was observed that growth and the proportion of living $L$. 608 pertusa decrease with age of the colony (Mortensen, 2001; Brooke \& Young, 2009; Lartaud et 609 al., 2013; Larcom et al., 2014; Vad et al., 2017).

610 Linear extension rates measured in laboratory studies on Lophelia pertusa were usually lower 611 than the field observations. Highest extension rates of $15-17 \mathrm{~mm} \mathrm{yr}^{-1}$ were obtained from 612 aquarium cultivations of L. pertusa from the Mediterranean Sea (Orejas et al., 2008). In an 613 elongated observation of this study, however, Orejas et al. (2011) measured a mean linear 614 extension rate of about $9 \mathrm{~mm} \mathrm{yr}^{-1}$, which is in accordance with linear extensions measured of $L$. 615 pertusa from different regions and through different analytical methods ranging from $\sim 5.5$ to 9.5 616 mm yr-1 (Mortensen \& Rapp, 1998; Mortensen, 2001; Roberts, 2002; Sabatier et al., 2012;

617 Lartaud et al., 2013).

618 Extension rates in almost all the studies were determined only of young and newly developed 619 corallites (Mortensen, 2001; Brooke \& Young, 2009), while older polyps grew with a rate of 1.3 $620 \pm 1.5 \mathrm{~mm} \mathrm{yr}^{-1}$ as specifically assessed by Lartaud et al. (2013). Taking only newly grown polyps’ 621 extension rates reveals also in the present study $34 \%$ higher extensions of the inshore corals in 622 Nord-Leksa compared to all stained corallites and even $52 \%$ higher extensions compared to 
623 older polyps only. Albeit variability in growth rates may be a result of differences in

624 methodological approaches, environmental conditions such as temperature, food supply,

625 turbidity, hydrography, and ocean chemistry are known to control the distribution of cold-water

626 corals and likely also influence the growth performance (i.e. Cairns \& Parker, 1992; Guinotte et

627 al., 2006; Thiem et al., 2006; White et al., 2007; Roberts et al., 2009; Georgian et al., 2016). The

628 drivers of ecosystem performance and how future changes will affect different populations of $L$.

629 pertusa and other cold-water coral bioherms are still not understood and need further

630 investigation through more in situ studies, in particular (Georgian et al., 2016).

631

632 Directly obtained in situ average linear extensions of all stained corallites on several branches in 633 the present study were in the same order of magnitude, but slightly lower than extension rates 634 reported for L. pertusa from the northern Gulf of Mexico, likewise measured in situ via the 635 Alizarin Red staining technique (Brooke \& Young, 2009). In their experiment, average extension 636 rates of $3.77 \mathrm{~mm} \mathrm{yr}^{-1}$ were measured in corals deployed at an area with a high coral density 637 (placed into coral thickets), while lower extension rates of $2.44 \mathrm{~mm} \mathrm{yr}^{-1}$ on average were 638 measured of corals placed in a usually non-inhabited area $\sim 0.25 \mathrm{~km}$ away from the coral area 639 after staining. The off-reef corals in the present study were placed less than $100 \mathrm{~m}$ away from the 640 reefs and no difference was observed in average extension between the on- and off-reef locations 641 in Nord-Leksa. However, the offshore corals from Sula Reef showed lower values of linear 642 extension than the fjord corals with $44 \%$ higher extension rates inshore compared to offshore 643 over the year. This finding is supported by the measured growth rates in weight gain, which even 644 showed twice as high calcification rates in the Leksa locations, although not significant. The 645 observed discrepancy in the differences among sites between the methods is most likely 646 attributable to the allometric growth of Lophelia, which is reflected more pronounced in the 647 assessment of linear extensions.

648 While the offshore corals constitute predominantly extending colonies with thick elongated 649 corallites, inshore colonies grow rather compact in bushy branches with shorter corallites. 650 Fragments that were size-wise similar to the Leksa fragments had less polyps/corallites and a 651 significantly smaller volume and surface area in Sula. The differences in morphology potentially 652 reflect the different environmental conditions the corals are exposed to, with the inshore corals 653 being more compact due to stronger currents, while corals in the Sula Reef can expand their 
654 corallites without enhanced risk of breakage. Freiwald et al. (1997) highlighted that Lophelia

655 growth forms and presumably also rates vary largely with environmental factors based on growth 656 rhythmicity observations and stable isotope data. Hence, growth rates might vary between in657 and offshore reef habitats due to physicochemical environmental factors such as current velocity, 658 oxygen saturation, light, trace elements, and food availability although the measured physical 659 seawater parameters and carbonate chemistry parameters did not vary considerably between 660 locations (Table 4). However, those parameters were instant samplings at the time when coral 661 cages were recovered. For comparison of environmental variability between sites, including 662 seasonal changes, environmental conditions should be monitored over a yearly cycle.

663 Comparing growth of living corals among locations revealed no significant differences between 664 in- and offshore reef sites or between on-reef / off-reef deployments, nor between white and 665 orange colonies. Only when all live coral fragments (white and orange) at each location are 666 pooled, results show a statistically significant difference between both 'off-reef' sites in the reefs 667 near Nord-Leksa and Sula. The higher growth rates at the inshore off-reef site would also apply 668 to the on-reef growth in Leksa if the rates were not so variable among all specimens, since these 669 corals exhibited even higher mean values. Thus, inshore growth rates were by trend higher than 670 in the Sula Reef. The $44-50 \%$ (extension - calcification) lower growth rates in Sula on average 671 may be explained by different deployment conditions, since these coral cages were placed on 672 relatively soft sediment ground approximately 50-100 m apart from the nearest reef structures, 673 while the off-reef corals at Nord-Leksa were situated on rather hard bottom, which is attributable 674 to the different habitat situations at the in- and offshore reef sites. Thus, lower growth rates of the 675 offshore corals might be a result of an inconvenient place the coral baskets were deployed at, 676 which might have been too far away from the reef, potentially too unsheltered with regard to 677 sedimentation and other environmental disturbances. However, looking at the fragments in the 678 aftermath, we observed more pronounced epibiont growth and sedimentation on the Leksa corals 679 than at Sula and also the polyp mortality was considerably higher in both fjord deployment sites. 680 In order to validate the trend of lower growth at the outer shelf compared to the fjord conditions, 681 this experiment should be repeated in Sula (or comparable offshore reef) with corals being 682 deployed closer to or directly into the reef using bigger fragments of live corals with comparable 683 volume like the fjord corals in order to enhance comparability to the inshore experimental 684 conditions. 


\section{White vs. orange colourmorphs}

687 Different phenotypes of L. pertusa of highly pigmented orange corals vs. the typical white 688 appearance were assessed. Growth rates expressed in weight gain showed a greater range in 689 orange corals compared to the white colourmorph. While white corals had maximum growth 690 rates of $0.019 \% \mathrm{~d}^{-1}$, the orange corals' growth rates reached up to $0.049 \% \mathrm{~d}^{-1}$, i.e. more than 691 twice as high in maximum growth rates. However, the average growth rate of orange corals was 692 only $30 \%$ higher and not significantly different from the white corals. While this was also true 693 in terms of average extension rates when taking means over all locations (18\% increased length 694 growth in orange compared to white specimens), the overall range of average extensions was 695 relatively similar in white and orange corals. So far, only few studies took a closer look into 696 physiological differences between the colourmorphs of L. pertusa and the physiological 697 advantages and potential costs of enhanced carotenoid concentrations in cold-water corals 698 remain unknown and require further investigation. Neulinger et al. (2008) hypothesised 699 nutritional differences of different colourmorphs by specific selection of certain bacterial 700 consortia associated only to orange or white corals. While orange corals host specific 701 gammaproteobacteria, which might utilise reduced sulfur compounds, white L. pertusa showed a 702 dominance of highly productive Rhodobacteracea, which can exploit even small amounts of organic material as carbon sources and which may support the nutrition of L. pertusa in environments with moderate carbon supply (Neulinger et al., 2008). Thus, the white phenotype may be able to inhabit deeper waters than orange corals. Here, the differences observed between groups were related to the different sites and environmental conditions rather than the two colourmorphs. With regard to mortality, however, the orange corals showed significantly less dead polyps than white corals. Hence, orange specimens seem to be more resistant to either the handling stress or environmental influences such as sedimentation. Together with the observed trend towards higher growth rates of orange corals in situ, the results of the present study suggest that the orange colourmorph is more resilient in the inshore reef at Nord-Leksa. If this is the case

712 and applies also to environmental changes, the orange phenotype may also be more resilient in

713 the future with regard to ocean change. But more physiological parameters, such as the metabolic 714 rates, need to be investigated to assess whether higher pigmentation gives rise to any kind of 
715 physiological advantage or higher stress resistance of the orange colourmorph of L. pertusa. At

716 least with regard to framework formation, colour variation does not seem to have adverse

717 impacts on the reef development, as it was recently shown that self-recognition even between

718 genetically distinct colonies of these two colour variants can lead to skeletal fusion (Hennige et

719 al., 2014b). The similar skeletal densities of white and orange corals as observed here thereby

720 probably facilitate skeletal fusion. No matter if simple overgrowth or allogeneic tissue fusion, the

721 ability of L. pertusa to self-recognise at a species level regardless of the phenotype or genotype

722 helps to reduce aggression-related energetic expenditure and supports cold-water coral reefs to

723 represent significant ecosystem engineers of the deep sea (Hennige et al., 2014b). Nevertheless,

724 the physiological mechanisms that lead to the higher robustness of orange colonies and the

725 relevance of pigmentation for future reef development warrant further investigation.

726

727 Mortality

728 Compared to recent laboratory studies with L. pertusa specimens from the same sites (e.g.

729 Büscher et al., 2017), polyp mortality in this in situ experiment was relatively high with $10-30$

$730 \%$ on average, depending on location. While the staining approach might have contributed to the

731 mortality, this was not observed during the recovery days in the tanks on board directly after

732 staining. Moreover, growth studies on L. pertusa using Alizarin as staining method did not show

733 enhanced mortality over prolonged experiments and no lethal effects were detected related to the

734 dye (Brooke \& Young, 2009; Form \& Riebesell, 2012; Lartaud et al., 2017).

735 A comparison of different sites revealed no significant differences in mortality, but a general

736 trend towards lower mortality in off-reef sites with lowest average percentage of dead polyps in

737 Sula in white and orange corals (65-67\% lower average percentage of dead polyps than at the

738 Leksa sites). Although levels of sedimentation were expected to be highest in Sula, where the

739 coral baskets were placed in relatively soft sediment, sediment particles as well as overgrowth by

740 epibionts were more pronounced on Leksa specimens and less on Sula corals. L. pertusa was

741 found to be fairly resilient to sediment loading, since this species efficiently cleans itself through

742 ciliary action and mucus shedding, and its survival is at risk only when completely buried for

743 several days (i.e. Brooke et al., 2009; Larsson \& Purser, 2011). Moreover, Brooke et al. (2009)

744 tested two different morphotypes of L. pertusa, the heavily calcified form with thick branches 
745 and the more fragile form with smaller branches and corallites, with regard to their tolerance

746 towards sedimentation and burial and found no difference between morphotypes. Thus,

747 differences in mortality among locations due to sedimentation in the different habitats and sites

748 or due to the different morphotypes between inshore and offshore branches are rather unlikely.

749 Instead, the higher mortality at the inshore sites may be related to stronger environmental

750 fluctuations with regard to abiotic factors such as temperature, salinity, and currents, as the

751 hydrodynamic conditions inshore are more variable than offshore. Moreover, elevated

752 concentrations of nutrients or pollutants due to aquacultures in the Trondheimsfjord, for

753 example, may be a possible explanation for higher polyp mortality inshore. Higher nutrient

754 levels inshore must yet be verified.

755 Orange specimens showed far lower mortality (less than a third) at all locations compared to 756 white specimens. In addition to slightly higher growth rates (18 - 30\%), this implies that another 757 underlying mechanism than environmental differences or handling stress causes coral mortality 758 to a different extent in the two colourmorphs.

\section{Bioerosion and accretion of dead coral framework}

761

762

763

764

765

766

767

768

769

770

771

772

773

\section{Bioerosion rates}

Although bioerosion contributes globally to a greater extent to reef degradation in marine habitats than physical erosion or passive chemical dissolution, this process is often being neglected in studies investigating coral growth and ocean change (Schönberg et al., 2017). Since ocean acidification is suspected to accelerate bioerosion, as experimentally demonstrated for chemical bioerosion by phototrophic microbial euendoliths and bioeroding sponges (e.g. Tribollet et al., 2006; 2009; Wisshak et al., 2012; 2013; 2014; Reyes-Nivia et al., 2013), $\mathrm{CaCO}_{3}$ degradation by bioeroders is an essential parameter to consider with regard to the impacts of ocean change on coral reef ecosystems. In this context, the in situ bioerosion rates reported herein may serve as base-line estimation for carbonate budget modelling assessments of Norwegian cold-water coral reefs.

772 A statistically highly significant difference was found between both off-reef placements and the Leksa on-reef location despite mixed bioeroded material in Sula, with the on-reef fragments 
774 exhibiting four times higher bioerosion rates. This may reflect a higher abundance and rate of

775 colonisation of bioeroders within the live reef structures and/or it may mirror environmental 776 conditions to be more favourable for bioeroders in that reef zone. The latter is supported by the

777 fact that the majority of macroborers in Lophelia skeletons (excavating sponges, bryozoans, and

778 polychaetes) are filter feeders that profit from the enhanced current regime and higher food 779 availability in the more exposed live zone of the reef. Bioerosion rates in the Sula Reef site and

780 the Leksa off-reef location, in contrast, were not significantly different. However, this might be a 781 result of the mixture of Sula and Leksa dead coral material in the Sula location with relatively 782 young bioeroded fragments from Sula. With more advanced bioerosion stages from Sula and 783 cage placements directly into the reef structures as in Nord-Leksa, bioerosion rates could perhaps 784 be higher in the Sula Reef.

785 Previously, the only experimentally determined bioerosion rates from a Lophelia reef

786 environment were those obtained via a settlement experiment carried out at the Säcken Reef in

787 the Swedish Kosterfjord (Wisshak, 2006), where pristine limestone tiles were subjected to

788 bioerosion for up to two years of exposure. During that experiment, the gravimetrically

789 determined bioerosion rates for the one year platforms were quantified as $-14 \pm 13 \mathrm{~g} \mathrm{~m}^{-2} \mathrm{yr}^{-1}$ and 790 were thus quite similar to the overall average of $-12.37 \pm 9.40 \mathrm{~g} \mathrm{~m}^{-2} \mathrm{yr}^{-1}$, but lower than the 791 Leksa on-reef bioerosion rates of $-23.20 \pm 7.87 \mathrm{~g} \mathrm{~m}^{-2} \mathrm{yr}^{-1}$ measured in the present study.

792 However, the Säcken Reef bioerosion rates were obtained from pristine substrates, as opposed to 793 an established bioeroder community like in the present study. Moreover, those results were 794 highly variable and perhaps of higher methodological uncertainty, since differences in weights 795 were very small and only little breakages through handling could have had an effect on the 796 changes in weight, leading to potential overestimation in bioerosion rates. The bioerosion rates 797 reported herein, in turn, need to be considered rather as a conservative estimation, since handling 798 stress during sampling, removal of calcareous epibionts, and re-deployment may have negatively 799 influenced or even killed part of the established bioeroders, such as the abundant bioeroding 800 sponges that are relatively sensitive to such disturbances (own observation). Other 801 methodological bias, including the removal of calcifying epibionts prior to and after the 802 experiment, trapped air bubbles during buoyant weighing sessions, breakage during deployment 803 or recovery, all potentially affect weighing results, but may also balance each other to some 804 extent. With no possibility to accurately quantify these factors, we have to assume that the 
805

806

807

808

809

810

811

812

813

814

815

816

817

818

819

820

821

822

823

824

825

826

827

828

829

830

831

832

833 834

overall bias is reasonably low and the calculated in situ bioerosion rates are the closest achievable approximation of a conservative estimate for total cold-water coral community bioerosion rates.

In any case, bioerosion rates within L. pertusa from the present study are considerably lower than rates determined from the analysis of coral samples or in situ settlement experiments of shallow-water tropical coral reefs around the globe (see Wisshak, 2006 for a review). Bioerosion rates from shallow-water reefs commonly surpass $1000 \mathrm{~g} \mathrm{~m}^{-2}$ (planar substrate surface) $\mathrm{yr}^{-1}$, which means they are about two orders of magnitude higher (see Kiene \& Hutchings, 1994; Peyrot-Clausade et al., 1995; Chazottes et al., 1995, Reaka-Kudla et al., 1996, and Tribollet et al., 2002 for examples). In addition to the fact that investigations of tropical reef substrates likely have a higher planar substrate surface available to bioerosion depending on the habitat complexity, this marked difference is a reflection of a general decrease in bioerosion rates with increasing water depths and higher latitudes. Decreasing bioerosion rates with depth primarily results from the depletion of photosynthetic microendoliths and grazers feeding upon them. Decreasing bioerosion rates towards higher latitudes again results from a temperature- and lightdependant depletion of phototrophic microborers as well as the lack of grazing parrot-fish as the most effective bioeroders in tropical seas (Wisshak et al., 2010; 2011).

To date, no experimental data are available testing the effects of ocean acidification and warming on cold-water coral bioerosion. Experiments with the demosponge Cliona celata in the coldtemperate North Sea (Wisshak et al., 2014) together with experimental evidence of increasing sponge bioerosion in tropical systems (e.g. Wisshak et al., 2012; 2013; and Schönberg et al., 2017 for a review) suggests that the observed feedback to ocean acidification likely applies across species and latitudes. There is no corresponding experimental data for marine fungi available to date, but data on other chemically acting microborers indicate that an increase of their bioerosion rate might apply to most bioeroders that actively lower the local $\mathrm{pH}$ in order to dissolve carbonate substrates (Schönberg et al., 2017). This suggests that not only sponge bioerosion is likely to increase in Lophelia reef environments, but also bioerosion by fungal and other microendoliths. More specific experimental evidence is needed to verify this hypothesis. 


\section{Carbonate accretion}

836 The rates of carbonate accretion by calcifying epibionts determined in the present in situ

837 experiment were surprisingly high and sometimes even compensated for bioerosion. Accretion

838 rates of epibionts on the dead coral framework averaged $0.003 \% \mathrm{~d}^{-1}$, comprising one fourth of

839 the rate of live coral growth. The higher rates of calcareous accretion in the dead coral

840 framework compared to the counteracting bioerosion processes were possibly caused by

841 unrealistically fast settlement on 'pristine' dead coral material due to the removal of calcifying

842 organisms prior to its deployment, which may have led to an increased rate of resettlement of the 843 available substrate.

844 The observed accretion of calcifying organisms on the live corals was likewise unusually high 845 for living corals, which might have resulted from handling of the corals prior to re-deployment.

846 Sampling and/or staining might have led to loss of some parts of the coenosarc, the corals' outer

847 epithelium, resulting in bare skeleton areas suitable for settlement of other organisms. Thus, 848 overgrowth - mainly consisting of shells from Delectopecten sp. - might have been facilitated by 849 unusually 'free' skeleton/substrate. In terms of measured accretion rates the abundance of 850 Delectopecten shells was, however, negligible, but was taken into account in growth rate 851 calculations of live coral growth.

\section{Conversion factors}

853 In our study we compared two established methods (buoyant weighing and linear extension 854 measurements) to directly assess natural growth rates of living corals and measured different 855 parameters to describe the coral fragments physically (e.g. weight, volume, polyp count). These 856 different approaches allowed for computing conversion factors of the corresponding parameters 857 to transform growth estimates based on buoyant weight measurements to linear extension rates 858 and vice versa, for example, and to convert standardisation parameters such as dry weight, 859 buoyant weight, volume and surface area of L. pertusa. This might be helpful in future studies 860 for a better comparability of different normalisations of physiological data of this species and for 861 broadening assumptions to non-measured parameters. 


\section{Conclusions}

863 The present in situ growth study revealed subtle to distinct differences in morphometry, colour

864 phenotype, growth, and bioerosion between populations of Lophelia pertusa from different

865 environmental settings. In situ community bioerosion rates were significantly higher in the live

866 reef structures compared to the two off-reef sites (in- and offshore), which is consistent with the

867 greater presence of bioeroders within the reef. With regard to calcification of living corals,

868 specimens from both inshore deployment sites at Nord-Leksa performed better than the ones

869 from the offshore Sula Reef. Besides, inshore corals showed a broader range of net accretion and

870 bioerosion rates between fragments than offshore, which might be attributable to a higher genetic

871 variation in the fjords. Being accustomed to a higher variability in environmental conditions, the

872 fjord reefs may be more resilient with regard to environmental changes, particularly if genetic

873 diversity supports adaptive responses to future ocean change (compare Kurman et al., 2017).

874 Orange specimens showed tendentially higher $\mathrm{CaCO}_{3}$ precipitation and a generally broader range

875 of net growth rates, as well as significantly lower polyp mortality. This may indicate a higher

876 stress-resistance of the higher pigmented corals, which could become prevalent for L. pertusa

877 reefs in the future with regard to environmental stressors induced by climate change.

878 The present study provides first net accretion rates of live corals as well as net erosion rates of

879 dead coral framework as first assessment of these two opposing processes in a cold-water coral

880 reef. Results indicate overall net accretion at all studied reef sites when directly comparing the

881 rates of both processes. However, to comparatively determine the balance between net accretion

882 and erosion on the ecosystem scale, compatible proportions of live and dead coral framework

883 (integrating coverage and organism abundance) need to be assessed in future studies in order to

884 quantify the relative contributions of both processes in a census-based approach (Reef Budget;

885 Perry et al., 2012). Reef budget analyses of reefs from various locations with differing

886 environmental conditions help to determine the present carbonate production states of cold-water

887 coral reefs and to understand the ecological drivers that influence reef growth dynamics. In

888 conjunction with net growth rate estimates under future ocean conditions, reef budgets would

889 further allow more precise assumptions about future reef resilience of cold-water coral

890 ecosystems. 


\section{Acknowledgements}

892 The captain and crew of RV POSEIDON are greatly thanked for support during the research 893 cruises POS455 and POS473 in 2013 and 2014, respectively. Our colleagues from the Institute of 894 Marine Research (IMR) in Bergen, Norway, as well as the Norwegian Environment Agency 895 (Miljø Direktoratet) and the German Federal Agency for Nature Conservation (BfN) are 896 acknowledged for support in the regulations of export and import permits for the specimens 897 following the Convention on International Trade in Endangered Species of Wild Fauna and Flora 898 (CITES). Prof. Dr. Arne-Jörn Lemke and Christian Timann are thanked for performing the CT 899 scans and their support during the measurements. The two anonymous reviewers and Carlos E. 900 Gómez are thanked for their constructive comments on an earlier version of this manuscript. 
901 References

902 Bell, N. \& Smith, J. (1999) Coral growing on North Sea oil rigs. Nature 402: 601.

903 Beuck, L. \& Freiwald, A. (2005) Bioerosion patterns in a deep-water Lophelia pertusa

904 (Scleractionian) thicket (Propeller Mound, northern Porcupine Seabight), In: Freiwald, A.,

905 Roberts, J.M. (Eds.), Cold-water Corals and Ecosystems. Springer, Berlin Heidelberg, pp. 915-

906936.

907 Beuck. L., López-Correa, M., Freiwald, A. (2008) Biogeographical distribution of Hyrrokkin

908 (Rosalinidae, Foraminifera) and its host-specific morphological and textural trace variability. In:

909 Wisshak M, Tapanila L (eds) Current Developments in Bioerosion. Springer, Berlin Heidelberg,

910 pp. 329-360.

911 Beuck, L., Freiwald, A., Taviani, M. (2010) Spatiotemporal bioerosion patterns in deep-water

912 scleractinians from off Santa Maria di Leuca (Apulia, Ionian Sea). Deep-Sea Research II 57,

$913 \quad 458-470$.

914 Bromley, R.G. (1994) The palaeoecology of bioerosion. In: Donovan SK (ed) The Palaeobiology 915 of Trace Fossils. Wiley, London, pp. 134-154.

916 Bromley, R.G. (2005) Preliminary study of bioerosion in the deep-water coral Lophelia,

917 Pleistocene, Rhodes, Greece, In: Freiwald, A., Roberts, J.M. (Eds.), Cold-water Corals and

918 Ecosystems. Springer, Berlin Heidelberg, pp. 895-914.

919 Brooke, S. \& Young, C.M. (2009) In situ measurement of survival and growth of Lophelia

920 pertusa in the northern Gulf of Mexico. Marine Ecology Progress Series 397: 153-161.

921 Brooke, S., Holmes, M.W., Young, C.M. (2009) Sediment tolerance of two different

922 morphotypes of the deep-sea coral Lophelia pertusa from the Gulf of Mexico. Marine Ecology

923 Progress Series 390: 137-144.

924 Brooke, S.D., Watts, M.W., Heil, A.D., Rhode, M., Mienis, F., Duineveld, G.C.A., Davies, A.J., 925 Ross, S.W. (2017). Distributions and habitat associations of deep-water corals in Norfolk and 926 Baltimore Canyons, Mid-Atlantic Bight, USA. Deep Sea Research Part II Topical Studies in 927 Oceanography 137: 131-147.

928 Büscher, J.V., Form, A.U., Riebesell, U. (2017) Interactive Effects of Ocean Acidification and 929 Warming on Growth, Fitness and Survival of the Cold-Water Coral Lophelia pertusa under 930 Different Food Availabilities. Frontiers in Marine Sciences 4 (101): 1-14.

931 Cairns, S.D. (1994) Scleractinia of the Temperate North Pacific. Smithsonian Contributions to 932 Zoology 557: i-150. 
933 Cairns, S.D. \& Parker, S.A. (1992) Review of the Recent Scleractinia (Stony Corals) of South

934 Australia, Victoria and Tasmania. Records of Southern Australian Museum, Monograph Series 3: $9351-82$.

936 Chazottes, V., Le Campion-Alsumard, T., Peyrot-Clausade, M. (1995) Bioerosion rates on coral 937 reefs: interactions between macroborers, microborers and grazers (Moorea, French Polynesia).

938 Palaeogeography, Palaeoclimatology, Palaeoecology 113: 189-198.

939 Davies, P.S. (1989) Short-term growth measurements of corals using accurate buoyant weighing 940 technique. Marine Biology 101(3): 389-395.

941 Dullo, W.-Chr., Flögel, S., Rüggeberg, A. (2008) Cold-water coral growth in relation to the 942 hydrography of the Celtic and Nordic European continental margin. Marine Ecology Progress 943 Series 371: 165-176.

944 Duncan, P.M. (1877) On the rapidity of growth and variability of some Madreporaria on an 945 Atlantic cable, with remarks upon the rate of accumulation of foraminiferal deposits.

946 Proceedings of the Royal Society of London 26: 133-137.

947 Elde, A.C., Pettersen, R., Bruheim, P., Järnegren, J., Johnsen, G. (2012) Pigmentation and 948 Spectral Absorbance Signatures in Deep-Water Corals from the Trondheimsfjord, Norway. 949 Marine drugs 10: 1400-1411.

950 Flögel, S., Dullo, W.-C., Pfannkuche, O., Kirikoulakis, K., Rüggeberg, A. (2014) Geochemical 951 and physical constraints for the occurrence of living cold-water corals. Deep-Sea Research II 99: 952 19-26.

953 Form, A.U., Riebesell, U. (2012) Acclimation to ocean acidification during longterm $\mathrm{CO}_{2}$ 954 exposure in the cold-water coral Lophelia pertusa. Global Change Biology 18(3): 843-853.

955 Form, A.U., Büscher, J., Hissmann, K., Flögel, S., Wisshak, M., Rüggeberg, A., Bannister, R., 956 Kutti, T., Stapp, L., Bennecke, S., Küter, M., Nachtigall, K., Schauer, J., Fenske, M. (2015) RV 957 POSEIDON Cruise Report POS473 LORELEI II: LOphelia REef Lander Expedition and 958 Investigation II, Tromsø - Bergen - Esbjerg, 15.08. - 31.08. - 04.09.2014. GEOMAR, Kiel, 25 959 pp.

960 Frederiksen, R., Jensen, A., Westerberg, H. (1992) The distribution of the scleractinian coral 961 Lophelia pertusa around the Faroe Islands and the relation to internal mixing. Sarsia 77: 157962171.

963 Freiwald, A., Heinrich, R., Pätzold, J. (1997) Anatomy of a deep-water coral reef mound from 964 Stjernsund, west Finnmark, northern Norway. In Cool-Water Carbonates, vol. 56 (eds. N. P. 965 James \& J. A. D. Clarke): Society for Sedimentary Geology, pp. 141-161. 
966 Freiwald, A., Hühnerbach, V., Lindberg, B., Wilson, J.B., Campbell J. (2002) The Sula Reef 967 complex, Norwegian Shelf. Facies 47: 179-200.

968 Freiwald, A., Fosså, J.H., Grehan, A., Koslow, T., Roberts, J.M. (2004) Cold-water coral reefs:

969 Out of sight - no longer out of mind. In UNEP-WCMC Biodiversity Series 22: UNEP World

970 Conservation Monitoring Centre, 86 pp.

971 Freiwald, A., Beuck, L., Rüggeberg, A., Taviani, M., Hebbeln, D. (2009) The white coral

972 community in the central Mediterranean Sea revealed by ROV surveys. Oceanography 22: 3697352.

974 Gass, S.E. \& Roberts, J.M. (2006) The occurrence of the cold-water coral Lophelia pertusa

975 (Scleractinia) on oil and gas platforms in the North Sea: Colony growth, recruitment and

976 environmental controls on distribution. Marine Pollution Bulletin 52: 549-559.

977 Gass, S.E. \& Roberts, J.M. (2011) Growth and branching patterns of Lophelia pertusa

978 (Scleractinia) from the North Sea. Journal of the Marine Biological Association of the United

979 Kingdom 91(4): 831-835.

980 GEOMAR Helmholtz-Zentrum für Ozeanforschung (2015) Research Vessel POSEIDON.

981 Journal of large-scale research facilities 1, A36.

982 GEOMAR Helmholtz-Zentrum für Ozeanforschung (2017) Manned submersible „JAGO“.

983 Journal of large-scale research facilities 3, A110.

984 Georgian, S.E., Deleo, D., Durkin, A., Gómez, C.E., Kurman, M., Lunden, J.J., Cordes, E.E.

985 (2016). Oceanographic patterns and carbonate chemistry in the vicinity of cold-water coral reefs

986 in the Gulf of Mexico: implications for resilience in a changing ocean. Limnology and

987 Oceanography 61: 648-665.

988 Gómez, C.E., Wickes, L., Deegan, D., Etnoyer, P.J., Cordes, E.E. (2018) Growth and feeding of 989 deep-sea coral Lophelia pertusa from the California margin under simulated ocean acidification 990 conditions. PeerJ 6: e5671.

991 Guinotte, J.M., Orr, J.C., Cairns, S.D., Freiwald, A., Morgan, L., George, R. (2006) Will human992 induced changes in seawater chemistry alter the distribution of deep-sea scleractinian corals?

993 Frontiers in Ecology and the Environment 4 (3): 141-146.

994 Hennige, S.J., Wicks, L.C., Kamenos, N.A., Bakker, D.C.E., Findlay, H.S., Dumousseaud, C., 995 Roberts, J.M. (2014a) Short-term metabolic and growth responses of the cold-water coral 996 Lophelia pertusa to ocean acidification. Deep-Sea Research Part II 99: 27-35.

997 Hennige, S.J., Morrison, C.L., Form, A.U., Büscher, J.V., Kamenos, N.A., \& Roberts, J.M. 998 (2014b) Self-recognition in corals facilitates deep-sea habitat engineering. Scientific Reports 4 999 (6782): 1-7. 
1000 Hennige, S.J., Wicks, L.C., Kamenos, N.A., Perna, G., Findlay, H.S., Roberts, J.M. (2015) 1001 Hidden impacts of ocean acidification to live and dead coral framework. Proceedings of the 1002 Royal Society B 282: 1-10.

1003 Hovland, M., Ottesen, D., Thorsnes, T., Fossa, J. H., Bryn, P. (2005) Occurrence and 1004 implications of large Lophelia-reefs offshore Mid Norway. In Onshore-Offshore Relationships 1005 on the North Atlantic Margin,eds. B. Wandas et al., NPF Special Publication 12, pp. 265-270.

1006 Hübscher, C., Dullo, W.C., Flögel, S., Titschack, J., Schönfeld, J. (2010) Contourite drift 1007 evolution and related coral growth in the eastern Gulf of Mexico and its gateways. International 1008 Journal of Earth Sciences 99: S191-S206.

1009 IPCC, 2014: Climate Change 2014: Synthesis Report. Contribution of Working Groups I, II and 1010 III to the Fifth Assessment Report of the Intergovernmental Panel on Climate Change [Core 1011 Writing Team, R.K. Pachauri and L.A. Meyer (eds.)]. IPCC, Geneva, Switzerland, 151 pp.

1012 Kennedy, E., Perry, C.T., Halloran, P.R., Iglesias-Prieto, R., Schönberg, C.H.L., Wisshak, M., 1013 Form, A.U., Carricart-Ganivet, J.P., Fine, M., Eakin, C.M., Mumby, P.J. (2013) Avoiding coral 1014 reef functional collapse requires local and global action. Current Biology 23: 912-918.

1015 Kiene, W.E. \& Hutchings, P.A. (1994) Bioerosion experiments at Lizard Island, Great Barrier 1016 Reef. Coral Reefs 13: 91-98.

1017 Kurman, M., Gómez, C.E., Georgian, S.E., Lunden J.J., Cordes, E. (2017) Intra-Specific 1018 Variation Reveals Potential for Adaptation to Ocean Acidification in a Cold-Water Coral from 1019 the Gulf of Mexico. Frontiers in Marine Science 4(111): 1-14.

1020 Larcom, E.A., McKean, D.L., Brooks, J.M., Fisher, C.R. (2014) Growth rates, densities, and 1021 distribution of Lophelia pertusa on artificial structures in the Gulf of Mexico. Deep-Sea 1022 Research Part I 85: 101-109.

1023 Larsson, A.I. \& Purser, A. (2011) Sedimentation on the cold-water coral Lophelia pertusa: 1024 Cleaning efficiency from natural sediments and drill cuttings. Marine Pollution Bulletin 62: 1025 1159-1168.

1026

1027

1028

1029

1030 1031

1032 1033
Lartaud, F., Pareige, S., De Rafelis, M., Feuillassier, L., Bideau, M., Peru, E., Romans, P., Alcala, F., Le Bris, N. (2013) A new approach for assessing cold-water coral growth in situ using fluorescent calcein staining. Aquatic Living Resources 26: 187-196.

Lartaud, F., Meistertzheim, A.L., Peru, E., Le Bris, N. (2017) In situ growth experiments of reefbuilding cold-water corals: The good, the bad and the ugly. Deep-Sea Research Part I 121: 70 78.

Lindberg, B. \& Mienert, J. (2005) Postglacial carbonate production by cold-water corals on the Norwegian Shelf and their role in the global carbonate budget. Geology 33(7): 537-540. 
1034 Lunden, J.J., McNicholl, C.G., Sears, C.R., Morrison, C.L., Cordes, E.E. (2014). Acute

1035

1036

1037

1038

1039

1040

1041

1042

1043

1044

1045

1046

1047

1048

1049

1050

1051

1052

1053

1054

1055

1056

1057

1058

1059

1060

1061

1062

1063

1064

1065

1066

1067

survivorship of the deep-sea coral Lophelia pertusa from the Gulf of Mexico under acidification, warming, and deoxygenation. Frontiers in Marine Science 1(78): 1-12.

Maier, C., Hegeman, J., Weinbauer, M.G., Gattuso, J.-P. (2009) Calcification of the cold-water coral Lophelia pertusa under ambient and reduced pH. Biogeosciences 6: 1671-1680.

Maier, C., Watremez, P., Taviani, M., Weinbauer, M.G., Gattuso, J.-P. (2012) Calcification rates and the effect of ocean acidification on Mediterranean cold-water corals. Proceedings of the Royal Society B 279: 1716-1723.

Mienis, F., Duineveld, G.C.A., Davies, A.J., Lavaleye, M.M.S., Ross, S.W., Seim, H., Bane, J., van Haren, H., Bergman, M.J.N., de Haas, H., Brooke, S., van Weering, T.C.E. (2014) Coldwater coral growth under extreme environmental conditions, the Cape Lookout area, NW Atlantic. Biogeosciences 11: 2543-2560.

Mikkelsen, N., Erlenkeuser, H., Killingley, J.S., Berger, W.H. (1982) Norwegian corals radiocarbon and stable isotopes in Lophelia pertusa. Boreas 11 (2): 163-171.

Mortensen, P.B. \& Rapp, H.T. (1998) Oxygen and carbon isotope ratios related to growth line patterns in skeletons of Lophelia pertusa (L.) (Anthozoa, Scleractinia): implications for determining of linear extension rates. Sarsia 83, 433-446.

Mortensen, P.B. (2001) Aquarium observations on the deep-water coral Lophelia pertusa (L., 1758) (Scleractinia) and selected associated invertebrates. Ophelia 54: 83-104.

Neulinger, S.C., Järnegren, J., Ludvigsen, M., Lochte, K., Dullo, W.C. (2008) Phenotypespecific bacterial communities in the cold-water coral Lophelia pertusa (Scleractinia) and their implications for the coral's nutrition, health, and distribution. Applied Environmental Microbiology 74: 7272-7285.

Neumann, A. (1966) Observation on coastal erosion in Bermuda and mesurement of the boring rate of sponge Cliona lampa. Limnology and Oceanography 11(1): 92-108.

Orejas, C., Gori, A., Gili, J.M. (2008) Growth rates of live Lophelia pertusa and Madrepora oculata from the Mediterranean Sea maintained in aquaria. Coral Reefs 27(2): 255.

Orejas, C. Ferrier-Pagès, C., Reynaud, S., Gori, A., Beraud, E., Tsounis, G., Allemand, D., Gili, J.M. (2011) Long-term growth rates of four Mediterranean cold-water coral species maintained in aquaria. Marine Ecology Progress Series 429: 57-65.

Orr, J.C., Fabry, V.J., Aumont, O., Bopp, L., Doney, S.C., Feely, R.A., Gnanadesikan, A., Gruber, N., Ishida, A., Joos, F., Key, R.M., Lindsay, K., Maier-Reimer, E., Matear, R., Monfray, P., Mouchet, A., Najjar, R.G., Plattner, G.K., Rodgers, K.B., Sabine, C.L., Sarmiento, J.L., Schlitzer, R., Slater, R. D., Totterdell, I.J., Weirig, M.F., Yamanaka, Y., Yool, A. (2005)

Peer) reviewing PDF | (2019:02:34849:1:1:REVIEW 1 Jul 2019) 
1068 Anthropogenic ocean acidification over the twentyfirst century and its impact on calcifying 1069 organisms. Nature 437(7059): 681-686.

1070 Perry, C.T., Spencer, T., Kench, P.S. (2008) Carbonate budgets and reef production states: a 1071 geomorphic perspective on the ecological phase-shift concept. Coral Reefs 27: 853-866.

1072 Perry, C.T., Edinger, E.N., Kench, P.S., Mumby, P.J., Murphy, G., Steneck, R.S., Smithers, S.G. 1073 (2012) Estimating rates of biologically driven coral reef framework production and erosion: a 1074 new census-based carbonate budget methodology and applications to the reefs of Bonaire. Coral 1075 Reefs 31: 853-868.

1076 Perry, C.T., Murphy, G.N., Kench, P.S., Edinger, E.N., Smithers, S.G., Steneck, R.S., Mumby, 1077 P.J. (2014) Changing dynamics of Caribbean reef carbonate budgets: emergence of reef 1078 bioeroders as critical controls on present and future reef growth potential. Proceedings of the 1079 Royal Society B 281: 20142018.

1080 Peyrot-Clausade, M., Le Campion-Alsumard, T., Hutchings, P.A., Le Campion, J., Payri, C., 1081 Fontaine, M.F. (1995) Initial bioerosion and bioaccretion on experimental substrates in high 1082 island and atoll lagoons (French Polynesia). Oceanologica Acta 18: 531-541.

1083 Provan, F., Nilsen, M.M., Larssen, E., Uleberg, K.-E., Sydnes, M.O., Lyng, E., Øysæd, K.B., 1084 Baussant, T. (2016) An evaluation of coral lophelia pertusa mucus as an analytical matrix for 1085 environmental monitoring: A preliminary proteomic study. Journal of Toxicology and 1086 Environmental Health Part A 79: 13-15: 647-657.

1087 Reaka-Kudla, M.L., Feingold, J.S., Glynn, W. (1996) Experimental studies of rapid bioerosion of 1088 coral reefs in the Galápagos Islands. Coral Reefs 15: 101-107.

1089

Reyes-Nivia, C. , Diaz-Pulido, G. , Kline, D. , Guldberg, O., Dove, S. (2013) Ocean acidification 1090 and warming scenarios increase microbioerosion of coral skeletons. Global Change Biology 19: 1091 1919-1929.

1092 Roberts, J.M. (2002) The Occurrence the Coral Lophelia pertusa and Other Conspicuous 1093 Epifauna around an Oil Platform in the North Sea. Journal of Society for Underwater 1094 Technology 25(2): 83-91.

1095 Roberts, J.M., Wheeler, A.J., Freiwald, A., Cairns, S.D. (2009) Cold-water Corals: The Biology 1096 and Geology of Deep-sea Coral Habitats. Cambridge: University Press.

1097 Roberts, J.M. \& Cairns, S.D. (2014) Cold-water corals in a changing ocean. Current Opinion in 1098 Environmental Sustainability 7: 118-126.

1099 Rogers, A.D. (1999) The biology of Lophelia pertusa (Linnaeus 1758) and other deep-water 1100 reef-forming corals and impacts from human activities. International Review of Hydrobiology 1101 84(4): 315-406. 
1102 Ross, S.W. \& Nizinski, M.S. (2007) State of deep coral ecosystems in the US southeast region:

1103 Cape Hatteras to southeastern Florida. In: Lumsden, S.E., Hourigan, R.F., Bruckner, A.W. Dorr.

1104 G. (Eds.), The State of Deep Coral Ecosystems of the United States. NOAA Technical

1105 Memorandum CRCP-3. Silver Spring, pp. 233-270, 365pp.

1106 Sabatier, P., Reyss, J.-L., Hall-Spencer, J. M., Colin, C., Frank, N., Tisnérat-Laborde, N., 1107 Bordier, L., Douville, E. (2012) ${ }^{210} \mathrm{~Pb}-{ }^{226} \mathrm{Ra}$ chronology reveals rapid growth rate of Madrepora 1108 oculata and Lophelia pertusa on world's largest cold-water coral reef. Biogeosciences 9: 125311091265.

1110 Schönberg, C.H.L., Fang, J.K.H., Carreiro-Silva, M., Tribollet, A., Wisshak, M. (2017) Bioerosion: the other ocean acidification problem. ICES Journal of Marine Science 74: 895-925.

1112 Schroeder, W.W. (2002) Observations of Lophelia pertusa and the surficial geology at a deepwater site in the northeastern Gulf of Mexico. Hydrobiologia 471: 29-33.

1114 Shnit-Orland, M. \& Kushmaro, A. (2008) Coral mucus bacteria as a source for antibacterial activity. Proceedings of the 11th International Coral Reef Symposium, Ft. Lauderdale, Florida, 7-11 July 2008.

1117 Stalling, D., Westerhoff, M., Hege, H.-C. (2005) 38 - Amira: a highly interactive system for 1118 visual data analysis. In: Visualization Handbook (Eds C.D. Hansen and C.R. Johnson), pp. 7491119 LXXVIII. Butterworth-Heinemann, Burlington.

1120 Thiem, Ø., Ravagnan, E., Fosså, J.H., Berntsen, J. (2006) Food supply mechanisms for coldwater corals along a continental shelf edge. Journal of Marine Systems 60: 207-219.

Titschack, J., Baum, D., De Pol-Holz, R., López-Correa, M., Forster, N., Flögel, S., Hebbeln, D., Freiwald, A. (2015) Aggradation and carbonate accumulation of Holocene Norwegian cold-water coral reefs. Sedimentology 62(7): 1873-1898.

Tribollet, A., Decherf, G., Hutchings, P.A., Peyrot-Clausade, M. (2002) Large-scale spatial variability in bioerosion of experimental coral substrates on the Great Barrier Reef (Australia): importance of microborers. Coral Reefs 21: 424-432.

Tribollet, A., Atkinson, M. J., Langdon, C. (2006) Effects of elevated $p \mathrm{CO}_{2}$ on epilithic and endolithic metabolism of reef carbonates. Global Change Biology 12: 2200-2208.

1130 Tribollet, A., Godinot, C., Atkinson, M., Langdon, C. (2009) Effects of elevated $p \mathrm{CO}_{2}$ on Area monitoring in a changing ocean. PeerJ 5: e3705. 
1135 White, M. (2007) Benthic dynamics at the carbonate mound regions of the Porcupine Sea Bight

1136

1137

1138

1139

1140

1141

1142

1143

1144

1145

1146

1147

1148

1149

1150

1151

1152

1153

1154

1155

1156

1157

1158

1159

1160

1161

1162 continental margin. International Journal of Earth Sciences 96: 1-9.

Wilson, J.B. (1979) The distribution of the coral Lophelia pertusa (L.) [L. prolifera] in the North-East Atlantic. Journal of the Marine Biological Association of the United Kingdom 59: 149-164.

Wisshak, M., Freiwald, A., Lundälv, T., Gektidis, M. (2005) The physical niche of the bathyal Lophelia pertusa in a non-bathyal setting: environmental controls and palaeoecological implications. In: Freiwald, A \& Roberts, JM (eds): Cold-water corals and ecosystems. Springer, Berlin Heidelberg, pp. 979-1001.

Wisshak, M. (2006) High-Latitude Bioerosion: The Kosterfjord Experiment. Springer, Berlin Heidelberg, Lecture Notes in Earth Sciences 109, 202 pp.

Wisshak, M. (2008) Two new dwarf Entobia ichnospecies in a diverse aphotic ichnocoenosis (Pleistocene/Rhodes, Greece), In: Wisshak, M., Tapanila, L. (Eds.), Current Developments in Bioerosion. Springer, Heidelberg, pp. 213-233.

Wisshak, M., Form, A., Jakobsen, J., Freiwald, A. (2010) Temperate carbonate cycling and water mass properties from intertidal to bathyal depths (Azores). Biogeosciences 7, 2379-2396.

Wisshak, M., Tribollet, A., Golubic, S., Jakobsen, J., and Freiwald, A. (2011) Temperate bioerosion: ichno- and biodiversity from intertidal to bathyal depths (Azores). Geobiology 9: $492-520$.

Wisshak, M., Schönberg, C.H.L., Form, A., Freiwald, A. (2012). Ocean acidification accelerates reef bioerosion. PLOS ONE 7: e45124.

Wisshak, M., Schönberg, C.H.L., Form, A., Freiwald, A. (2013) Effects of ocean acidification and global warming on reef bioerosion - lessons from a clionaid sponge. Aquatic Biology 19: $111-127$.

Wisshak, M., Schönberg, C.H.L., Form, A., Freiwald, A. (2014). Sponge bioerosion accelerated by ocean acidification across species and latitudes? Helgoland Marine Research 68: 253-262.

Zheng, M.-D. \& Cao, L. (2015) Simulation of global ocean acidification and chemical habitats of shallow- and cold-water coral reefs. Advances in Climate Change Research 5(4): 189-196. 
Figure $\mathbf{1}$ (on next page)

Live coral and bioerosion cages deployed within living reef structures (on-reef, A) and on the sediment in the off-reef location (B) in Nord-Leksa.

Image courtesy: JAGO-Team, GEOMAR Kiel. 

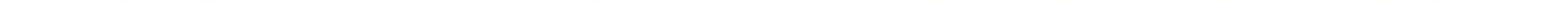
Figure 2 (on next page)

Example images of the $\mathrm{CT}$ scans of (A) a live coral fragment (orange coral branch from Leksa on-reef) and (B) dead coral framework from one basket of the cluster (Leksa offreef). 


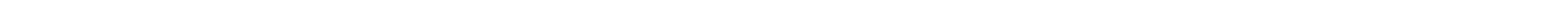

B
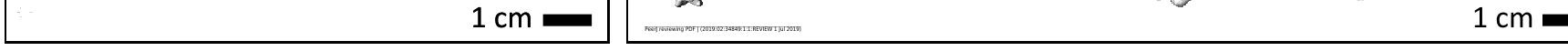
Figure 3 (on next page)

Mortality (in percent dead polyps per branch) of white and orange corals at three deployment sites.

Error bars represent \pm standard deviation (SD) of white and orange corals each at the inshore on-reef and off-reef deployment locations at Nord-Leksa, and at the Sula Reef. 
Figure 4 (on next page)

Mortality (in percent dead polyps per branch) of white and orange corals averaged over all three locations.

Error bars represent \pm standard deviation. The asterisk denotes that there is a statistically significant difference $(P=0.002)$ of the percentage of polyp mortality between white and orange corals. 
Figure $\mathbf{5}$ (on next page)

Exemplary branches of the stained live corals of a white $(A+B)$ and an orange $(C+D)$ coral from the Nord-Leksa on-reef location.

Photos $\mathbf{B}$ and $\mathbf{D}$ depict close-ups of the most distant polyps of the coral branches from $\mathbf{A}$ and

C. Linear extension rates were measured from the Alizarin Red S staining mark to the terminal, unstained rim of the calices. 
Figure 6 (on next page)

Average linear extension rates (in $\mathrm{mm}$ per year) of white and orange corals over one year at the three deployment sites Leksa on-reef, Leksa off-reef, and Sula Reef.

Number of replicates (n) per site and colour morphotype is indicated next to the bars. Error bars represent \pm standard deviation. 


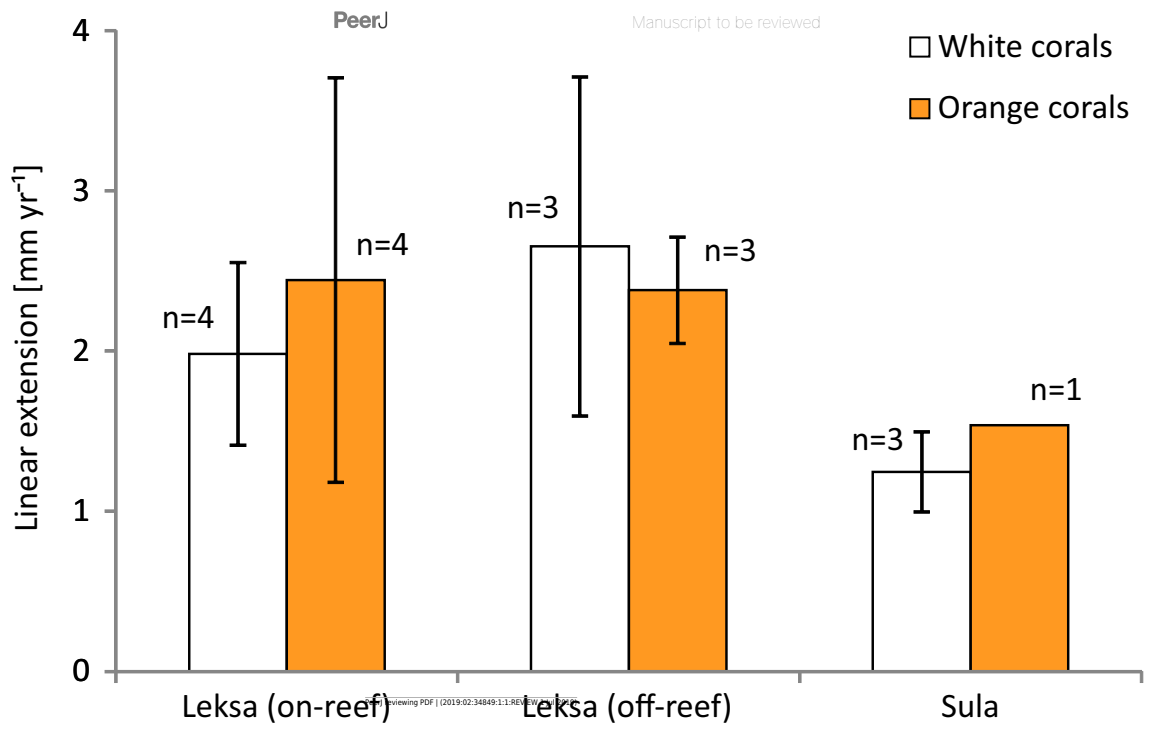


Figure 7 (on next page)

Average linear extension rates (in mm per year) of inshore (Leksa) and offshore (Sula) live corals.

Given are mean extension rates of pooled white and orange corals in $\mathrm{mm}$ per year \pm standard deviation as error bars. The asterisk denotes a statistically significant difference between inshore and offshore corals when white and orange corals are pooled at both locations $(P=0.03)$. 
Figure 8 (on next page)

Average linear extension rates (in $\mathrm{mm}$ per year) of total stained polyps and polyps grown newly after staining.

Data are averaged over all three reef sites. Error bars represent \pm standard deviation. The asterisk denotes that there is a statistically significant difference between only newly grown polyps and all stained polyps in average linear extension $(P=0.04)$. 
Figure 9 (on next page)

Growth rates (calcification) of live corals and bioerosion and accretion rates of dead coral framework averaged over all three deployment sites.

Given are mean net calcification rates of live corals averaged over all locations and colourmorphs as well as bioerosion rates of the dead erect coral fragments and accretion rates of calcifying fauna on the dead framework averaged over the deployment sites. Error bars represent \pm standard deviation and the number of replicates $(n)$ is indicated next to the bars. 
Figure 10 (on next page)

Growth (calcification) and bioerosion rates of one year in situ investigation at the three deployment sites Leksa on-reef, Leksa off-reef, and Sula Reef.

Average calcification rates of white and orange $L$. pertusa, and bioerosion rates of dead coral framework and associated carbonate accretion by calcifying epibionts (in percent per day) over one year of exposure. Error bars represent \pm standard deviation and the number of replicates $(n)$ is indicated next to the bars, respectively. 


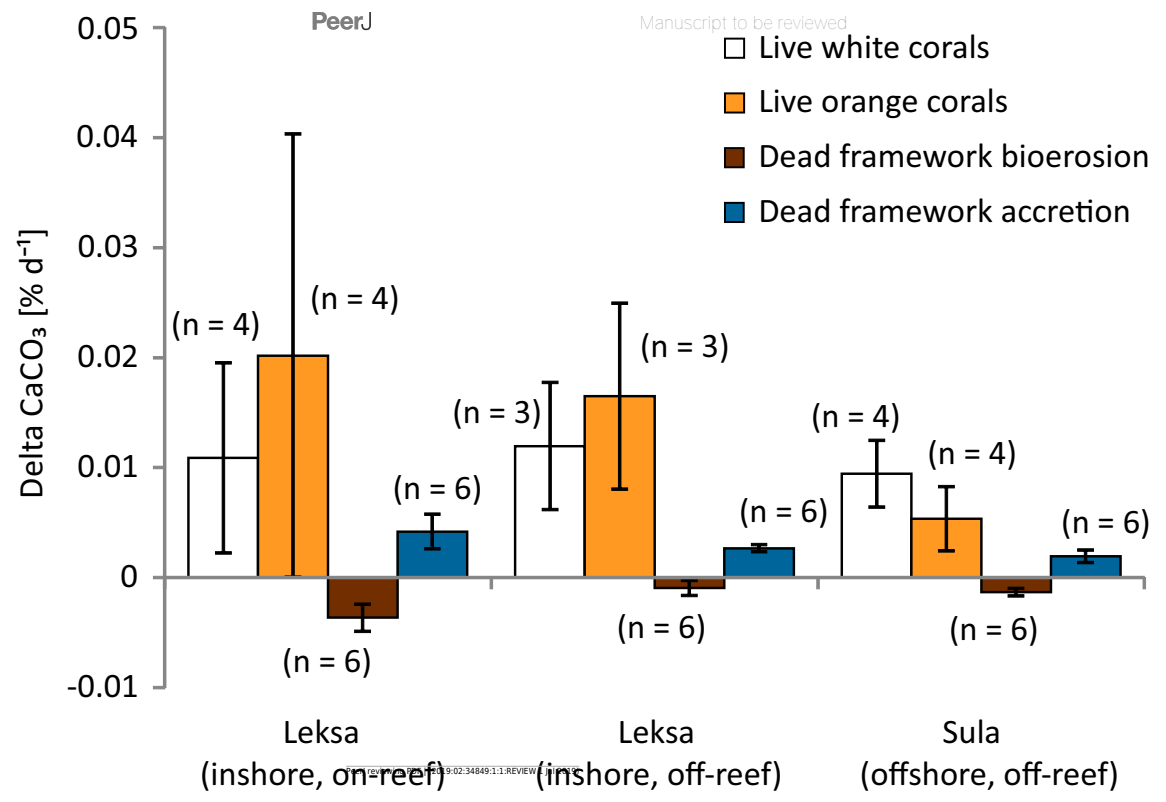




\section{Table $\mathbf{1}$ (on next page)}

Coral surface area, volume, and skeletal density of live and dead coral fragments as well as polyp counts of live corals.

Surface area (in $\mathrm{mm}^{2}$ ) and volume (in $\mathrm{mm}^{3}$ ) are calculated from CT scans and given for live white and orange coral fragments as average of all replicates $(n=4$ white as well as orange corals at Leksa on-reef and Sula, and $n=3$ white as well as orange corals at Leksa off-reef) standard deviation at the three deployment locations. 


\begin{tabular}{|c|c|c|c|c|c|}
\hline Location & Replicates & Surface area $\left(\mathrm{mm}^{2}\right)$ & Volume $\left(\mathrm{mm}^{3}\right)$ & $\begin{array}{c}\text { Polyps / } \\
\text { corallites }(\mathbf{N})\end{array}$ & $\begin{array}{c}\text { Skeletal density } \\
\left(\mathrm{g} \mathrm{cm}^{-3}\right)\end{array}$ \\
\hline \multirow{3}{*}{$\begin{array}{c}\text { Leksa } \\
\text { (inshore, } \\
\text { on-reef) }\end{array}$} & $\begin{array}{l}\text { White } \\
\text { corals }\end{array}$ & $51074.1 \pm 1793.9$ & $36403.1 \pm 5607.8$ & $126 \pm 55$ & $2.764 \pm 0.011$ \\
\hline & $\begin{array}{l}\text { Orange } \\
\text { corals }\end{array}$ & $30064.7 \pm 11692.6$ & $21150.5 \pm 11044.0$ & $91 \pm 10$ & $2.733 \pm 0.057$ \\
\hline & $\begin{array}{l}\text { Dead } \\
\text { framework }\end{array}$ & $172819.7 \pm 12298.6$ & $144023.3 \pm 13345.2$ & - & $2.777 \pm 0.024$ \\
\hline \multirow{3}{*}{$\begin{array}{c}\text { Leksa } \\
\text { (inshore, } \\
\text { off-reef) }\end{array}$} & $\begin{array}{l}\text { White } \\
\text { corals }\end{array}$ & $44529.3 \pm 8823.8$ & $34855.6 \pm 7881.5$ & $111 \pm 33$ & $2.746 \pm 0.031$ \\
\hline & $\begin{array}{l}\text { Orange } \\
\text { corals }\end{array}$ & $48469.5 \pm 23321.8$ & $32660.8 \pm 17937.6$ & $154 \pm 57$ & $2.700 \pm 0.022$ \\
\hline & $\begin{array}{l}\text { Dead } \\
\text { framework }\end{array}$ & $169054.3 \pm 11319.0$ & $141679.3 \pm 13145.4$ & - & $2.770 \pm 0.010$ \\
\hline \multirow{3}{*}{$\begin{array}{c}\text { Sula } \\
\text { (offshore, } \\
\text { off-reef) }\end{array}$} & $\begin{array}{l}\text { White } \\
\text { corals }\end{array}$ & $20323.5 \pm 7228.6$ & $13304.7 \pm 5139.5$ & $38 \pm 10$ & $2.722 \pm 0.062$ \\
\hline & $\begin{array}{l}\text { Orange } \\
\text { corals }\end{array}$ & $16063.2 \pm 5236.2$ & $11052.1 \pm 3955.8$ & $33 \pm 12$ & $2.411 \pm 0.135$ \\
\hline & $\begin{array}{l}\text { Dead } \\
\text { framework }\end{array}$ & $141404.2 \pm 15298.4$ & $110715.6 \pm 11055.5$ & - & $2.727 \pm 0.030$ \\
\hline
\end{tabular}

\section{1}

2 


\section{Table 2 (on next page)}

Percent mortality of white and orange coral branches after one year of deployment.

The percentage of polyp mortality per branch is given as replicate means \pm standard deviation for each deployment location and colourmorph. 


\begin{tabular}{|ccc}
\hline Location & $\begin{array}{c}\text { Mortality rate } \\
\text { white (\%) }\end{array}$ & $\begin{array}{c}\text { Mortality rate } \\
\text { orange (\%) }\end{array}$ \\
\hline Leksa (inshore, on-reef) & $48 \pm 26$ & $12 \pm 14$ \\
\hline Leksa (inshore, off-reef) & $33 \pm 19$ & $9 \pm 7$ \\
\hline Sula (offshore, off-reef) & $18 \pm 17$ & $3 \pm 5$ \\
\hline Mean of all locations: & $33 \pm 23$ & $8 \pm 9$ \\
Mean all live corals: & \multicolumn{2}{|c}{$20 \pm 22$} \\
\hline
\end{tabular}

1 


\section{Table 3 (on next page)}

Calcification and linear extension rates of live corals at three different deployment sites over one year experimental duration.

Rates (in percent per day $\left(\% \mathrm{~d}^{-1}\right)$ as well as grams per square metre and year $\left(\mathrm{g} \mathrm{m}^{-2} \mathrm{yr}^{-1}\right)$ for

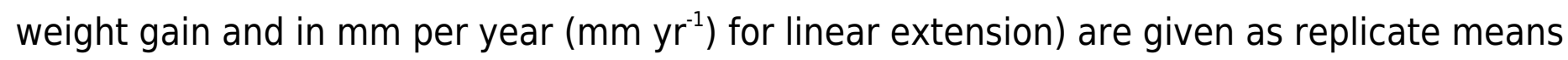
\pm standard deviation per deployment site for white and orange corals. The calcification rate in $\mathrm{g} \mathrm{m}^{-2} \mathrm{yr}^{-1}$ is based on surface area of the coral substrate calculated from the CT scans (see text for details). 


\begin{tabular}{|c|c|c|c|c|c|c|}
\hline Location & $\begin{array}{l}\text { Calcification } \\
\text { rate - white } \\
\left(\% \mathbf{d}^{-1}\right)\end{array}$ & $\begin{array}{l}\text { Calcification } \\
\text { rate - orange } \\
\left(\% \mathbf{d}^{-1}\right)\end{array}$ & $\begin{array}{l}\text { Calcification } \\
\text { rate - white } \\
\left(\mathrm{g} \mathrm{m}^{-2} \mathrm{yr}^{-1}\right)\end{array}$ & $\begin{array}{l}\text { Calcification } \\
\text { rate - orange } \\
\left(\mathrm{g} \mathrm{m}^{-2} \mathrm{yr}^{-1}\right)\end{array}$ & $\begin{array}{l}\text { Linear } \\
\text { extension - white } \\
\left(\mathrm{mm} \mathrm{yr} \mathbf{r}^{-1}\right)\end{array}$ & $\begin{array}{l}\text { Linear } \\
\text { extension - orange } \\
\left(\mathbf{m m ~} \mathrm{yr}^{-1}\right)\end{array}$ \\
\hline $\begin{array}{l}\text { Leksa } \\
\text { (inshore, } \\
\text { on-reef) }\end{array}$ & $0.0109 \pm 0.0086$ & $0.0202 \pm 0.0203$ & $56.07 \pm 42.31$ & $99.31 \pm 86.73$ & $1.98 \pm 0.57$ & $2.44 \pm 1.26$ \\
\hline $\begin{array}{l}\text { Leksa } \\
\text { (inshore, } \\
\text { off-reef) }\end{array}$ & $0.0120 \pm 0.0058$ & $0.0165 \pm 0.0085$ & $74.01 \pm 38.94$ & $76.80 \pm 45.83$ & $2.65 \pm 1.06$ & $2.38 \pm 0.33$ \\
\hline $\begin{array}{l}\text { Sula } \\
\text { (offshore, } \\
\text { off-reef) }\end{array}$ & $0.0095 \pm 0.0030$ & $0.0053 \pm 0.0030$ & $42.49 \pm 6.82$ & $28.51 \pm 15.03$ & $1.25 \pm 0.25$ & $1.54(\mathrm{n}=1)$ \\
\hline $\begin{array}{l}\text { Mean of all } \\
\text { locations: }\end{array}$ & $0.0107 \pm 0.0057$ & $0.0138 \pm 0.0137$ & $56.02 \pm 32.01$ & $67.42 \pm 61.51$ & $1.96 \pm 0.84$ & $2.31 \pm 0.90$ \\
\hline $\begin{array}{l}\text { Mean all } \\
\text { live corals: }\end{array}$ & \multicolumn{2}{|c|}{$0.0122 \pm 0.0103 \% \mathrm{~d}^{-1}$} & \multicolumn{2}{|c|}{$61.72 \pm 48.20 \mathrm{~g} \mathrm{~m}^{-2} \mathrm{yr}^{-1}$} & \multicolumn{2}{|c|}{$2.12 \pm 0.86$} \\
\hline
\end{tabular}

1 


\section{Table 4 (on next page)}

Carbonate chemistry and physical seawater properties at three deployment locations (inshore at two sites in the Trondheimsfjord (Leksa on- and off-reef) and offshore at the Sula Reef).

Environmental seawater properties measured from samples taken directly at the coral cages deployment sites at the time of recovery in 2014. Water samples were collected by means of the NISKIN bottle of JAGO for measurements of total alkalinity (TA) and dissolved inorganic carbon (DIC) (in $\mu \mathrm{mol}$ per kg seawater). Physical seawater parameters (temperature (T) and salinity (Sal)) were measured with a CTD attached to JAGO (GEOMAR, 2017). Remaining carbonate chemistry parameters $\left(\mathrm{CCO}_{2}\right.$, bicarbonate $\left(\mathrm{HCO}_{3}{ }^{-}\right)$, carbonate $\left(\mathrm{CO}_{3}{ }^{2-}\right)$, and the aragonite saturation $\left.\left(\Omega_{\mathrm{Ar}}\right)\right)$ were computed with CO2SYS. 


\begin{tabular}{|c|c|c|c|c|c|c|c|c|c|c|c|c|}
\hline Location & Latitude & Longitude & $\begin{array}{c}\text { Depth } \\
{[\mathbf{m}]}\end{array}$ & $\begin{array}{c}\mathbf{T} \\
{\left[{ }^{\circ} \mathbf{C}\right]}\end{array}$ & Sal & $\begin{array}{l}\text { DIC } \\
{\left[\mu \mathrm{mol} \mathrm{kg}{ }^{-1}\right]}\end{array}$ & $\begin{array}{l}\text { TA } \\
{\left[\mu \mathrm{mol} \mathrm{kg}{ }^{-1}\right]}\end{array}$ & $\mathbf{p} \mathbf{H}_{\mathrm{TS}}$ & $\begin{array}{c}p \mathrm{CO}_{2} \\
{[\mu a t m]}\end{array}$ & $\begin{array}{l}\mathrm{HCO}_{3}^{-} \\
{[\mu \mathrm{mol} \mathrm{kg-1}]}\end{array}$ & $\begin{array}{l}\mathrm{CO}_{3}^{2-} \\
{\left[\mu \mathrm{mol} \mathrm{kg}^{-1}\right]}\end{array}$ & $\mathbf{\Omega}_{\mathrm{Ar}}$ \\
\hline Nord-Leksa 'on-reef' & $63^{\circ} 36.486^{\prime} \mathrm{N}$ & $09^{\circ} 22.947^{\prime} \mathrm{E}$ & 180 & 7.7 & 35.1 & 2157.0 & 2306.7 & 7.994 & 453.5 & 2022 & 113.6 & 1.7 \\
\hline Nord-Leksa 'off-reef' & $63^{\circ} 36.535^{\prime} \mathrm{N}$ & $09^{\circ} 22.891^{\prime} \mathrm{E}$ & 219 & 7.7 & 35.4 & 2136.3 & 2310.0 & 8.052 & 390.7 & 1990 & 127.8 & 1.9 \\
\hline Sula Reef & $64^{\circ} 06.643^{\prime} \mathrm{N}$ & $08^{\circ} 07.060^{\prime} \mathrm{E}$ & 304 & 7.5 & 35.5 & 2142.6 & 2312.9 & 8.043 & 399.8 & 1998 & 125.8 & 1.9 \\
\hline
\end{tabular}




\section{Table 5 (on next page)}

Bioerosion and carbonate accretion rates of the dead coral framework over one year experimental duration at one o $\square$ shore and two inshore deployment sites.

Rates are given in percent bioerosion as well as carbonate accretion per day $\left(\% \mathrm{~d}^{-1}\right)$, and in grams per coral framework surface and year $\left(\mathrm{g} \mathrm{m}^{-2} \mathrm{yr}^{-1}\right)$. Data are presented as replicate means $\square$ standard deviation for all three locations (Leksa on-reef, Leksa o $\square$-reef, Sula Reef). 


\begin{tabular}{|c|c|c|c|c|}
\hline Location & $\begin{array}{l}\text { Bioerosion rate } \\
\qquad\left(\% \mathbf{d}^{-1}\right)\end{array}$ & $\begin{array}{l}\text { Accretion rate } \\
\qquad\left(\% \mathbf{d}^{-1}\right)\end{array}$ & $\begin{array}{l}\text { Bioerosion rate } \\
\left(\mathrm{g} \mathrm{m}^{-2} \mathrm{yr}^{-1}\right)\end{array}$ & $\begin{array}{l}\text { Accretion rate } \\
\left(\mathrm{g} \mathrm{m}^{-2} \mathbf{y r}^{-1}\right)\end{array}$ \\
\hline $\begin{array}{l}\text { Leksa } \\
\text { (inshore, on- } \\
\text { reef) }\end{array}$ & $-0.0036 \pm 0.0012$ & $0.0042 \pm 0.0016$ & $-23.20 \pm 7.87$ & $26.58 \pm 9.74$ \\
\hline $\begin{array}{l}\text { Leksa } \\
\text { (inshore, off- } \\
\text { reef) }\end{array}$ & $-0.0009 \pm 0.0007$ & $0.0027 \pm 0.0003$ & $-5.88 \pm 4.42$ & $17.13 \pm 2.45$ \\
\hline $\begin{array}{l}\text { Sula } \\
\text { (offshore, off- } \\
\text { reef) }\end{array}$ & $-0.0013 \pm 0.0003$ & $0.0019 \pm 0.0006$ & $-8.03 \pm 2.24$ & $11.74 \pm 3.41$ \\
\hline $\begin{array}{l}\text { Mean of all } \\
\text { locations: }\end{array}$ & $-0.0020 \pm 0.0015$ & $0.0029 \pm 0.0013$ & $-12.37 \pm 9.40$ & $18.48 \pm 8.54$ \\
\hline
\end{tabular}

1 


\section{Table 6(on next page)}

Calculated conversion factors of growth rates and structural parameters.

Factors translating growth rates of living corals from daily percentage $\left(\% \mathrm{~d}^{-1} / \mathrm{g} \mathrm{m}^{-2} \mathrm{yr}^{-1}\right)$ into linear extension $\left(\mathrm{mm} \mathrm{d}^{-1} / \mathrm{yr}^{-1}\right)$ and vice versa, as well as conversions of diffent standardisation parameters such as weight, volume or surface area (short 'Area'), and polyp count ( $\mathrm{N}$ of polyps). Conversions are given for white and red corals separately and for both combined ('All live corals'). 


\begin{tabular}{|c|c|c|c|}
\hline & White corals & Orange corals & All live corals \\
\hline $\begin{array}{l}G\left(\% d^{-1}\right) \\
\rightarrow \text { Linear extension }\left(\mathrm{mm} \mathrm{d}^{-1}\right)\end{array}$ & $0.439 \pm 0.125$ & $0.456 \pm 0.194$ & $0.447 \pm 0.155$ \\
\hline $\begin{array}{l}\text { Linear extension }\left(\mathrm{mm} \mathrm{d}^{-1}\right) \\
\rightarrow \mathbf{G}\left(\% \mathbf{d}^{-1}\right)\end{array}$ & $2.040 \pm 0.991$ & $2.325 \pm 1.060$ & $2.167 \pm 1.056$ \\
\hline $\begin{array}{l}\mathrm{G}\left(\mathrm{g} \mathrm{m}^{-2} \mathrm{yr}^{-1}\right) \\
\rightarrow \text { Linear extension }\left(\mathrm{mm} \mathrm{yr}^{-1}\right)\end{array}$ & $0.035 \pm 0.019$ & $0.038 \pm 0.015$ & $0.037 \pm 0.017$ \\
\hline $\begin{array}{l}\text { Linear extension }\left(\mathrm{mm} \mathrm{yr}^{-1}\right) \\
\rightarrow \mathbf{G}\left(\mathrm{g} \mathrm{m}^{-2} \mathrm{yr}^{-1}\right)\end{array}$ & $30.34 \pm 15.30$ & $31.28 \pm 14.03$ & $30.76 \pm 14.43$ \\
\hline $\begin{array}{l}\text { Area }\left(\mathrm{mm}^{2}\right) \\
\rightarrow \text { Volume }\left(\mathrm{mm}^{3}\right)\end{array}$ & $0.709 \pm 0.095$ & $0.677 \pm 0.070$ & $0.693 \pm 0.083$ \\
\hline $\begin{array}{l}\text { Volume }\left(\mathrm{mm}^{3}\right) \\
\rightarrow \text { Area }\left(\mathrm{mm}^{2}\right)\end{array}$ & $1.435 \pm 0.201$ & $1.492 \pm 0.153$ & $1.464 \pm 0.177$ \\
\hline $\begin{array}{l}\text { Volume }\left(\mathrm{mm}^{3}\right) \\
\rightarrow \text { Dry Weight }(\mathrm{g})\end{array}$ & $0.002 \pm 0.000$ & $0.002 \pm 0.000$ & $0.002 \pm 0.000$ \\
\hline $\begin{array}{l}\text { Dry Weight (g) } \\
\rightarrow \text { Volume }\left(\mathbf{m m}^{3}\right)\end{array}$ & $501.88 \pm 23.29$ & $515.27 \pm 23.80$ & $508.58 \pm 23.98$ \\
\hline $\begin{array}{l}\text { Area }\left(\mathrm{mm}^{2}\right) \\
\rightarrow \text { Dry Weight }(\mathrm{g})\end{array}$ & $1422.24 \pm 248.19$ & $1321.02 \pm 194.56$ & $1371.63 \pm 223.70$ \\
\hline $\begin{array}{l}\text { Dry Weight }(g) \\
\rightarrow \text { Area }\left(\mathbf{m m}^{2}\right)\end{array}$ & $724.16 \pm 134.19$ & $772.03 \pm 113.52$ & $748.09 \pm 123.58$ \\
\hline $\begin{array}{l}\text { N of polyps } \\
\rightarrow \text { Dry Weight (g) }\end{array}$ & $0.672 \pm 0.210$ & $0.522 \pm 0.219$ & $0.597 \pm 0.223$ \\
\hline $\begin{array}{l}\text { DW }(\mathrm{g}) \\
\rightarrow \mathrm{N} \text { of polyps }\end{array}$ & $1.566 \pm 0.517$ & $1.998 \pm 0.731$ & $1.772 \pm 0.650$ \\
\hline $\begin{array}{l}\text { N of polyps } \\
\rightarrow \text { Area }\left(\mathrm{mm}^{2}\right)\end{array}$ & $474.03 \pm 128.58$ & $385.58 \pm 124.65$ & $429.80 \pm 131.61$ \\
\hline $\begin{array}{l}\text { Area }\left(\mathbf{m m}^{2}\right) \\
\rightarrow \mathrm{N} \text { of polyps }\end{array}$ & $0.002 \pm 0.001$ & $0.003 \pm 0.001$ & $0.003 \pm 0.001$ \\
\hline $\begin{array}{l}\text { Nof polyps } \\
\rightarrow \text { Volume }\left(\mathrm{mm}^{3}\right)\end{array}$ & $334.91 \pm 97.04$ & $265.49 \pm 104.09$ & $300.20 \pm 104.43$ \\
\hline $\begin{array}{l}\text { Volume }\left(\mathrm{mm}^{3}\right) \\
\rightarrow \mathrm{N} \text { of polyps }\end{array}$ & $0.003 \pm 0.001$ & $0.004 \pm 0.002$ & $0.004 \pm 0.001$ \\
\hline $\begin{array}{l}\text { Buoyant (g) } \\
\rightarrow \text { Dry weight (g) }\end{array}$ & $1.536 \pm 0.008$ & $1.536 \pm 0.005$ & $1.536 \pm 0.011$ \\
\hline $\begin{array}{l}\text { Dry weight (g) } \\
\rightarrow \text { Buoyant weight }(\mathrm{g})\end{array}$ & $0.651 \pm 0.004$ & $0.651 \pm 0.002$ & $0.651 \pm 0.005$ \\
\hline
\end{tabular}

1 